\title{
Rüzgârdan Enerji Üretiminin Sosyo-Mekânsal Duyarlılık Alanları: İzmir Örneği
}

\author{
Socio-spatial Sensitivity Areas in Wind Energy Transition: \\ The Case of Izmir
}

\author{
Başak Demir, ${ }^{1}$ (D) Anlı Ataöv²
}

${ }^{1}$ Çankaya Üniversitesi Mimarlık Fakültesi, Şehir ve Bölge Planlama Bölümü, Ankara

${ }^{2}$ Orta Doğu Teknik Üniversitesi Mimarlık Fakültesi, Şehir ve Bölge Planlama Bölümü, Ankara

\section{ÖZ}

Artan nüfus, gelişen sanayi ve fosil yakıt temelli donanıma sahip günümüz yaşam koşulları nedeniyle enerji ihtiyacı giderek artmaktadır. Bu çerçevede enerji ihtiyacına uzun vadeli çözüm arayışında yenilenebilir enerji kaynaklarına geçiş ön plana çıkmakta; ancak zaman zaman bu süreçlerde toplum tepkisiyle karşılaşılmaktadır. Bu çalışma, önemli bir yenilenebilir kaynak olan rüzgâra odaklanarak; Türkiye'deki tesislerin beşte birinin ve yoğun toplum tepkisinin yer aldığı İzmir bağlamında rüzgârdan enerji üretme sürecini toplumsal bir bakış açısıyla değerlendirmektedir. Rüzgârdan enerji üretiminin toplumsal algıda yer eden doğal çevre ve ekonomik yaşam (tarım, hayvancılık), duyusal (görüntü bütünlüğüne etki, gürültü), sağlık (insan sağlığına etki), teknolojik (manyetik alan ve türbin sayısı) alanlardaki duyarlııkları tespit edilerek, bireysel ve kolektif algıyı temsil eden görüşler ortaya koyulmaktadır. Bulgular toplumsal duyarlılı̆ın geçerliliğini göstermektedir; bununla birlikte ifade edilen konuları sorun olarak görmeyen bir görüşün de olduğu görülmektedir. Bu durum, etkinin olmadığı düşüncesi ile ya da başkalarından duyduğuna dayanarak duyarlılık değerlendirmesi yapıldığı olasılığını da gündeme getirmektedir. Çalışmanın bulguları İzmir bağlamında, sayıca giderek artan rüzgâr tesislerinin toplumda rüzgâr enerjisi konusunda bir "doygunluk" oluşturduğunu; tesislerin yer seçiminde doğa ve insan faaliyetlerinin gerçekleştiği alanlara olan "mesafe" koşulunun belirlenmesi ve buna paralel olarak tesislerin belli bir alanda yoğunlaşması ile gelişen kümülatif etkinin de dikkate alınması gerektiğini ortaya koymaktadır. Ayrıca bu süreçlerde halkın yer alması gerekliliği ve bilgilenme ihtiyacı açıkça görülmektedir. Anahtar sözcükler: Rüzgar enerjisi; toplumsal duyarlılık alanları; toplumsal tepki.

\begin{abstract}
Growing energy need is obvious considering the increasing population, industrial development, together with today's fossil fuel based living conditions. Within this framework renewable energy transition is inevitable in search for a long-term solution to this growing energy need. However, several public oppositions are encountered during such transition processes. This study focuses on the wind energy - an important source of renewable energy - in case of Izmir which is the leading city in Turkey in terms of number of wind farms as well as intensive public oppositions. Study reveals social sensitivity areas of wind energy production regarding natural environment and economic life (agriculture, animal husbandry), sensory (effect on visual integrity, noise), health (effect on human health), technological (magnetic field and turbine number) issues. The study reveals individual and collective perceptions about the sensitivity areas, on the other hand, there is an opinion that does not consider the expressed issues as a problem. The findings show the validity of social sensitivity, but also raise the possibility of making sensitivity assessment based on the thought that there is no such thing or what he heard from others. According to the findings of the study, increasing number of wind farms within the context of İzmir creates a "saturation" among the society about wind energy. In this respect, "minimum distance" criteria should be determined for the wind farm site selection to the areas where nature and human activities take place. "Cumulative effect" caused by the concentration of wind farms in a certain area should also be taken into consideration. Finally, public participation during these processes and being informed is urgent.
\end{abstract}

Keywords: Wind energy; social sensitivity areas; public opposition.

Geliş tarihi: 03.12.2020 Kabul tarihi: 21.05.2021

Online yayımlanma tarihi: 27.05.202I

İletişim: Başak Demir

e-posta: bdemir@cankaya.edu.tr 


\section{Giriş}

Değişen iklim koşulları, sürdürülemez büyüme hızı ve ekolojik düzendeki önemli kırılmalar ve yıkımlar, yenilenebilir enerji kaynaklarının kullanımını ön plana çıkartmaktadır (IEA, 20I5; IPCC, 2012, 2020; Yılmaz, 20I2). Rüzgârdan enerji üretimi, enerji kapasitesi ve ekonomik olarak diğer yenilenebilir enerji kaynaklarına göre daha verimli görülmektedir (Kılıç vd., 20I7). Bu nedenle, rüzgârdan enerji üretiminin merkezi düzeyde ulusal ve uluslararası anlaşmalar, raporlar, yasa ve politikalarla desteklendiği ve bunun toplumun tüm kesimleri tarafından benimsenmesine yönelik bir beklenti olduğu izlenmektedir (Aitken, 2010; Kılıç vd., 2017). Ancak, rüzgârdan enerji üretiminin gelişimi hakkındaki kararlar, toplumsal kaygıları dikkate almamaktadır. Bu durum toplumun tepki göstermesi için meşru bir temel yaratmaktadır. Bu türde alınan ve uygulanan kararlar, halk için düş kırıcı, mutsuz ve tatminsiz bir deneyime dönüşmekte, halkı sonunda rüzgâr enerjisi gelişimine itiraz etmeye götürmektedir. İtiraz konularının temelinde, yenilenebilir enerji hakkındaki kararların insan ve çevre üzerinde dayatmacı olması yatmaktadır. Bununla birlikte, rüzgârdan enerji üretimine maruz bırakılmak, adaletsizlik söylemi üzerinden toplumun duygusal bir tepki vermesine neden olmaktadır (DuPont, 1981; Short, 2002; Wolsink, 2000).

Rüzgârdan enerji üretimi teknoloji-yoğun bir süreç olarak yürütülmektedir (Toja-Silva vd., 20I3; Tetra Tech, 2008). Buna karşılık, toplumun verdiği geribildirimler, bunun aslında toplumsal bir süreç olduğuna dair de ipuçları vermektedir. Özellikle, Avrupa ve Kuzey Amerika'da son 20 yıldır, teknoloji odaklı çalışmalara kıyasla rüzgâr enerjisinin toplumsal boyutu ile ilgili yürütülen daha az sayıda çalışma olduğu bilinmektedir. Türkiye bağlamına özgün rüzgârdan enerji üretimi üzerine yapılmış bazı çalışmalara rastlanmakla birlikte (Altaş, 1998; Aydın, 2013; Koç, 1996; Özgener, 2002), toplumsal konuları ele alan çalışmalar sayıca oldukça azdır (Kılıç vd., 20।7; Palabıyık vd. 20।0). Bu durum, Türkiye'de rüzgârdan enerji üretim uygulamalarının merkezi düzeyde "yaygınlaştırılması" hedefi ve özel sektöre yönelik teşviklerin geliştirilmesi ile toplumsal önceliğin ikinci plana düşmesi; bununla birlikte, bu konunun dikkate alınmadığı uygulamaların çoğalması sonucunda tepkilerin son dönemlerde başlamış olması olarak açılanabilir. Söz konusu gelişmeler, rüzgârdan enerji üretimine toplumsal bir süreç olarak bakma ihtiyacını vurgulamakta, toplumsal boyutu ele alan çalışmaların yapılması ihtiyacını doğurmaktadır. Türkiye, Avrupa'daki rüzgârdan enerji üretme potansiyeline en fazla sahip ve son yıllarda rüzgârdan enerji üretim hedeflerini oldukça yüksek tarif etmiş bir ülke olarak görülmektedir (TÜREB, 2019). T. C. Enerji ve Tabii Kaynaklar Bakanlığı tarafından hazırlanan Türkiye Ulusal Yenilenebilir Enerji Eylem Planı (2014) 2023 yılında 20.000 MW rüzgâr enerji potansiyelinin işletilir hale gelmesini öngörmektedir. Bu hedefe ulaşabilmek için özel sektörün katılımıyla rüzgâr enerji tesislerinin kurulması merkezi yönetim tarafından desteklenmekte, ancak süreç, mekânsal planlarla eşgüdüm içinde ilerlemekten ziyade tesisleri lisanslama biçiminde yürütülmektedir. Genel olarak, 24 ile 36 ay arasında değişen bu süreç, (i) ön lisans, (ii) Çevre Etki Değerlendirme (ÇED), (iii) kurumsal görüş alma, (iv) mülkiyet değişimi, (v) imar planlarının revizyonu ve (vi) Enerji Piyasası Düzenleme Kurumu (EPDK) onayını içeren altı aşamadan oluşmaktadır. Buna göre, ön lisans kapsamında firma tarafından EPDK'ya sunulan enerji üretimi yapma talebini, Çevre ve Şehircilik Bakanlığı bünyesinde gerçekleşen ve $50 \mathrm{MW}$ üzerindeki başvurular için geçerli olan ÇED süreci takip etmektedir. Rüzgâr tesislerini kurmak için önerilen alanın kullanım ve statü özelliğine göre (doğal çevre, orman, kültürel miras, tarım alanı, askeri alan gibi) sayısı 25-30'a kadar çıkabilen ilgili tüm bakanlık ve kurumlardan görüş yazısı alınmaktadır. Olumlu görüş ve onayların alınması üzerine söz konusu arazinin, mevcut statüsünden çıkartılıp Enerji Bakanlığı üzerinden kamuya transfer ya da kamulaştırma yoluyla, mülkiyet değişikliği gerçekleştirilmekte, bunu imar planının tadilatı aşaması takip etmektedir.

Çok boyutlu bir biçimde ele alınması beklenen, oldukça uzun ve özel sektör için stresli geçen bu süreç, farklı kademelerdeki (il ve ilçe) planlama süreçlerinden bağımsız olarak yürütülmekte, etkileri dikkate alınması gereken bir yer seçimi konusundan ziyade birçok kurumun dahil olduğu salt bürokratik bir lisans alma işine dönüşmektedir. Yenilenebilir enerji öncelikli kamusal yarar olarak tanımlandığı için rüzgâr enerji tesisleri ekolojik değeri olan alanlar da dahil olmak üzere, kültürel miras, su, orman ve tarım alanları gibi hem doğal ve kültürel değeri olan hem de sosyo-ekonomik faaliyetlerin yapıldı̆̆ı özel alanların yanında ya da içinde yer seçebilmektedir. Bunun yanı sıra, rüzgâr tesislerinin bu tip özel alanlara ve insan yerleşimlerine olan uzaklığına duyarlı bir mevzuat bulunmamakta; mevcut yasal uygulamaların yaptırımları ise kısıtlı kalmaktadır. Bu durum, rüzgârdan enerji üretimine karşı toplumsal tepkinin oluşmasına zemin hazırlamaktadır. Öte yandan, Türkiye'de katılımlı planlama süreçleri, yasal olarak sadece halkın görüşünü alan bir katılım seviyesinde tarif edilmekte olup, pratikte ise, karar verme süreçlerine katılım yöneticilerin inisiyatiflerine bağlı olarak uygulanmaktadır.

Türkiye bağlamında, rüzgârdan enerji üretim sürecinde toplumun yerinin ve rolünün göreceli olarak yetersiz tarif edilmiş olması ve bu yüzden etkisiz kalması nedeniyle merkezi bir bakış açısıyla yürütülen sürecin yerelle uzlaşıcı olması yerine yerelde tepkisel karşılandığı gözlemlenmektedir. Bu da, rüzgârdan enerji üretim sürecine teknik çözümlerin üstünde toplumsal ve yerele özgü bir duyarlılık ile yaklaşılması ihtiyacını doğurmaktadır. Böyle bakıldığında, bu süreçte birbiriyle ilişkili iki konu ön plana çıkmaktadır. Birincisi, toplumsal tepkilerin oluşum süreçlerinin irdelenmesi, bu kapsamda mevzuatın izin verdiği fırsatlar çerçevesinde ulusal düzeyde yürütülen rüzgârdan enerji gelişim sürecine yerelde dahil olamayan ak- 
törlerin toplumsal örgütlenmelerinin, organize olma kapasitelerinin, bunu tetikleyen psiko-sosyal dinamiklerin, toplumsal tepkilerinin ve biçimlerinin kendi bağlamlarına göre anlaşılmasıdır. İkincisi, rüzgârdan enerji üretim sürecinde rüzgar tesislerinin yer seçimlerinden kaynaklı toplumda gelişen duyarlılık alanlarının tanımlanmasıdır.

Buradan yola çıkarak, bu yazı, önemli bir yenilenebilir enerji kaynağı olan rüzgârdan enerji üretim sürecini toplumsal bir bakış açısıyla değerlendirmekte ve yereldeki sosyal ve mekânsal konularla ilişkili duyarlılığı mercek altına almaktadır. Bunu, Türkiye'nin rüzgârdan enerji üretiminin beşte birinin $(\% \mid 9,2)$ ve en yoğun kurulu rüzgâr gücünün yer aldığı, ve Türkiye'deki toplumsal düzeyde en fazla "ret" sesi getiren İzmir (TÜREB, 2019) örneği üzerinden yapmaktadır. Bu kapsamda, İzmir ilinde, farklı büyüklükteki enerji santrallerine farklı uzaklıklarda olan 8 yerleşimde yürütülen betimleyici araştırma bulgularını sunarak Türkiye bağlamına özgün ipuçlarını keşfetmeye çalışmaktadır. Toplumsal tepkilerin oluşum süreçleri ve bağlamsal örgütlenmeleri ile ilgili kuramsal çerçeve ve araştırma bulguları ayrıntılı bir tartışmayı gerektirdiği için başka bir yazı konusu olarak ele alınacaktır.

Yazı dört bölümü içermektedir. Önce, çoğunlukla Avrupa ve Kuzey Amerika ülkelerinde yapılmış çalışmaları temel alarak, enerji gelişim sürecinin toplumsal boyutuyla ilgili yapılan kuramsal tartışmalar sunulmaktadır. Sonra, yürütülen araştırmanın yöntemsel kurgusu paylaşılmaktadır. Üçüncü bölümde, araştırma bulguları, son bölümde, bulguların değerlendirilmesi ve toplumla bütünleşik rüzgâr enerji üretimine yeni bakış açısı önerileri verilmektedir.

\section{Rüzgâr Enerjisinin Toplum ile İlişkisinin İpuçları}

Küresel ısınma ve yerel düzeyde yaşanan çevre problemleri ile yenilenebilir enerjinin önemi ve gerekliliği ön plana çıkmaktadır. 1980’lerden beri yürütülen araştırmalar küresel iklim değişikliğinin nedenlerinden \%75'inin enerji tüketiminden kaynaklandığını ortaya koymaktadır (IEA, 20I5). Türkiye genelinde, Türkiye Elektrik İletim A. Ş.'nin 2018 yılında yayınladığı son raporuna göre 2013-2018 yılları arasında yıllık üretilen elektriğin yaklaşık \%70'i fosil yakıtlar (doğal gaz, taş kömürü, asfaltit, linyit ve termik) kullanılarak üretilmiştir. Oysa, ülkemizde oldukça sınırlı sayıda petrol, kömür ve doğal gaz yatakları bulunmakta; 2018 yılında her üç kaynak için de üretimin tüketime oranı \%।0'un altında kalmaktadır (TEIAŞ, 20।8). Bu veriler Türkiye'nin enerji ihtiyacını karşılamakta kullandığı kaynakların çok büyük bir kısmını doğrudan yurtdışından temin ettiğini göstermektedir. Buna karşılık, doğal yaşam döngüsü devam ettiği sürece var olacak rüzgârın, enerji üretim tesisleri duyarlı ve sürdürülebilir bir şekilde yer seçtiği sürece yaygınlaşabilme potansiyeline sahip olduğu da bilinmektedir.
Buna paralel olarak, rüzgârın da içinde olduğu yenilenebilir kaynaklardan enerji üretimi ile ilgili ülkesel ve bölgesel büyük hedefler belirlenmektedir ancak toplumun bu tür bir enerji üretimini kabul edip etmeyeceği sorgulanmamaktadır. Yenilenebilir enerji üretimi, üretim teknolojilerini geliştirmeye odaklı teknik bir süreç olarak ele alınmaktadır. Bu, teknolojiyi insan ve doğa ile karşı karşıya bırakmaktadır. Rüzgârdan enerji üretmek sadece teknolojik bir faaliyet değildir; toplumsal boyutu da düşünülmelidir. Nitekim, bu boyuta odaklanan çalışmalar, rüzgârdan enerji üretiminden kaynaklanan yereldeki "gerilim" veya "kabul” üzerinde durmaktadır (Kılıç vd., 2017). Buna referansla, bir yandan, Arka Bahçemde Olmasın Tutumu (NIMBY-Not In My Backyard) gibi duyarlılık hareketleri ve/veya yerel tepkileri tartışan (örnek: Burningham, 2000; Devine-Wright, 2005; Swofford ve Slattery, 2010) ve rüzgâr enerjisine karşı bireysel/toplumsal tepkileri farklılaştıran nedenleri araştıran (örnek: Gype, 1995; Simon, 1996; Krohn ve Damborg, 1999; Wolsink, 1988) çalışmalar varken; öte yandan, rüzgârdan enerji üretiminin toplumsal etkilerini tartışan çalışmalara (örnek: Devine-Wright, 2007; Wolsink, 2012; Wüstenhagen vd. 2007) rastlanmaktadır. Bu çalışmalar, rüzgâr enerji tesislerinin kurulumunun yerelde bazı tepkilerle sonuçlandığını vurgulamakta, bu tepkilerin yönünü (olumlu ve olumsuz gibi) ve düzeyini (direnç, muhalefet, ret gibi) belirleyen tutum, yaklaşım, bilgilenme, ekonomik ortaklık gibi yönlendiricileri araştırmakta ve toplumun rüzgâr tesislerinden dolayı duyarlılık geliştirdiği alanları göstermektedir (Şekil I). Tüm bu çıkarımlar, rüzgârdan enerji üretim biçiminin teknolojik gelişim ile olan ilişkisinin yanında toplum ve yerellik ile olan bağının kurulması ihtiyacını ortaya koymaktadır.

Yurtdışında yapılan toplumsal odaklı çalışmaların çıktıları araştırmanın yapıldığı bölgelerdeki yerel toplumsal özellikleri yansıtmakta olup, bunların Türkiye'ye ne kadar uygun olup olmadığı bir araştırma konusudur. Türkiye'nin bağlamsal özellikleri çerçevesinde rüzgârdan enerji üretiminin toplumda yarattığı gerilimi ele alan kısıtlı sayıda çalışma (Güzel, 20।3; Özçam, 2016; Peker, 2013, 2005) genelde tutum, beklentiler ve aktörler arası ilişkiler üzerinedir. Bu çalışmalar, çatışma durumlarını tartışmakta ve çözüm yollarını araştırmaktadır. Rüzgâr enerjisi üretiminde toplumu rüzgârdan enerji üretimini kabule veya bu üretim biçimini reddetmeye götüren hassasiyet alanlarını bilimsel olarak anlamaya ihtiyaç vardır. Nitekim, bu yazıda sunulan araştırmanın temel amacı da budur.

Buradan yola çıkarak, bu bölümde rüzgâr enerjisinin toplumsal boyutuna odaklanan uluslararası çalışmalardan örnekler verilmektedir. Bunlar iki temel grupta toplanabilir. Birinci grupta yer alan çalışmalar, toplumun rüzgar enerjisine karşı tutumu ve tepkileri ile ilgili olup, dört başlıkta incelenmektedir: (i) rüzgarın diğer enerji kaynakları ile karşılaştırıldığında, (ii) rüzgar tesislerinin yanında olup olmadığında, (iii) enerji üretiminden gelen ekonomik faydanın parçası olunduğunda ve 


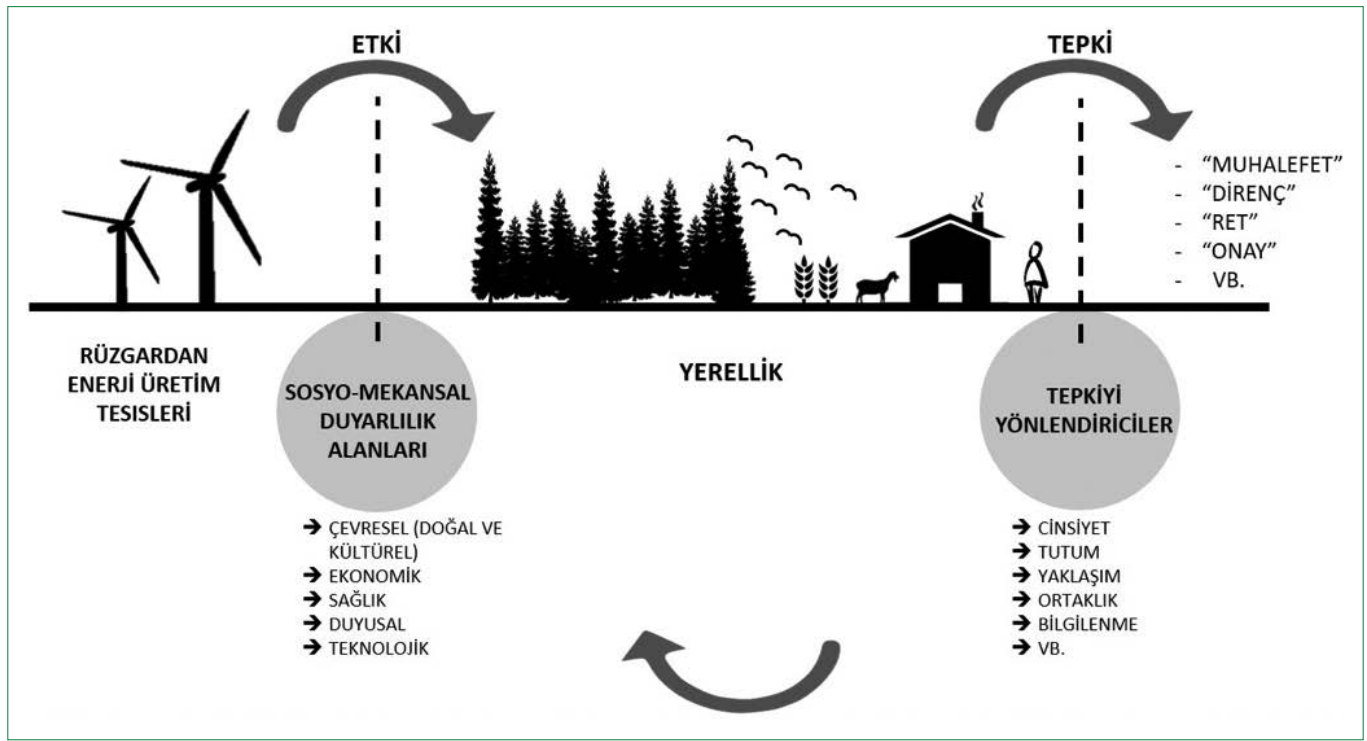

Şekil I. Rüzgâr tesisleri etkileri, sosyo-mekânsal duyarlılık alanları, yerellik, tepki ve tepkiyi yönlendiriciler.

bilgilenildiğinde ve (iv) rüzgardan enerji üretimi ile ilgili bakış açısına göre rüzgar enerji üretiminin toplumsal olarak nasıl desteklendiğine veya rahatsızlık seviyesinin nasıl değişsiğine bakılmaktadır.

Toplumsal boyuta odaklanan ikinci grup çalışmalar, rüzgârdan enerji üretim sürecinde toplumun etkilendiği alanların ortaya çıkartılması ile ilgilidir. Bunlar, (i) çevresel (doğal ve kültürel), (ii) ekonomik, (iii) duyusal ve (iv) teknolojik olarak gruplandırılabilir. Bu kısımda, ayrıca, toplumsal hassasiyetin oluşmasıyla ilişkili olabilecek rüzgâr tesislerinin yer seçiminde yukarıdaki doğal çevre, ekonomik faaliyet ve yerleşim alanlarına uzaklığı, Türkiye ve Avrupa ülkelerindeki yasal uygulamalar temel alınarak karşılaştırmalı olarak değerlendirilmektedir.

\section{I Toplumsal Tepki ve Yönlendiricileri}

Toplumsal tepkiye odaklanan ilk grup çalışmalar, yenilenebilir enerji kaynaklarını diğer fosil yakıtlar ile karşılaştırarak halkın tercihine ve desteğine bakmaktadır. Bu konuda en sık atıfta bulunulan çalışma, Krohn ve Damborg'un (1999) 1990'lı yıllarda İngiltere, ABD, Kanada, İsveç, Almanya, Hollanda ve Danimarka ülkelerinde yapılan araştırmaları incelediği çalışmadır. Krohn ve Damborg'un (1999) değerlendirmeleri, yenilenebilir enerjinin genel olarak tercih edildiğini göstermektedir. Amerikalıların \%42'si enerji araştırmalarında federal bütçeden yenilenebilir enerjinin destek almasını en öncelikli konu olarak belirtmekte; enerjinin en fazla üretildiği fosil yakıtlar ve nükleer enerji, sırası ile $\% 7$ ve $\% 9$ ile son sırada yer almaktadır (Breglio, 1995). Benzer şekilde, Danimarka'da da yenilenebilir enerjiye karşı halkın tavrının olumlu olduğu ifade edilmektedir (DWTMA, 1993). Her 5 Danimarkalıdan 4'ü yenilenebilir enerjinin enerji politikasında öncelikli bir konu olması gerektiğini belirtmekte, bu görüşe katılmayanlar ise sadece \%9'u temsil etmektedir. Ulusal enerji politikaları ve bütçeleri içerisinde yenilenebilir enerjinin önceliği yukarıdaki çalışmalarda tespit edilmekte olup, Kanadalıların \%79'unun yenilenebilir enerjiyi kendi kullanımları açısından değerlendirdikleri ve kendi bölgelerinde elektriği satın aldıkları üretici firmanın rüzgâr enerjisine öncelik vermesi gerektiğine inandıkları yönündedir (Omnibus Report, 1995). DWTMA’nın (1993) yürüttüğü Tutum Anketine (Holdningsundersogelse) göre, Danimarkalıların \%82'si Danimarka'nın daha fazla rüzgâr enerjisinden yararlanması gerektiğini düşünmektedir; Gype'ın (1995) çalışması Hollandalıların \%80'inin rüzgâr enerjisini desteklerken, \%5'inin karşı çıktığını ve \%ı5'inin ise kayıtsız kaldığını belgelemektedir. Ingiltere'de, 1990-1996 yılları arasında gerçekleştirilen I3 araştırma ise 10 kişiden 8'inin rüzgâr enerjisini desteklediğini ortaya koymaktadır (Simon, 1996).

2000'li yıllarda, Avusturalya, New South Wales'de (NSW) 2000'den fazla bölge sakini ve 300 işletmeyle yapılan anket çalışması sonuçları, çalışmaya katılanların \%85'inin NSW'deki, \%80'inin yaşadıkları yerdeki rüzgâr tesis gelişimlerini desteklediğini göstermektedir (AMR Interactive, 2010). IPSOS'un 2010'da Türkiye'nin de içinde bulunduğu 23 ülkede uyguladığı anket çalışması ise, yenilenebilir enerji kaynaklarının, fosil yakıtlar ve nükleer enerjiye göre \%50-70 daha fazla desteklendiğini göstermektedir (IPSOS, 20I0). Fukushima Nükleer Tesisi'nde gerçekleşen kazadan sonra, IPSOS'un 2012'de tekrarladığı çalışma, yenilenebilir enerji kaynaklarının fosil yakıt ve nükleer enerjiye göre benzer oranlarda desteklendiği sonucunu ortaya koymaktadır (IPSOS, 2012).

İkinci çalışma grubu "Arka Bahçemde Olmaz" (NIMBY-Not In My Back Yard) tutumuna odaklanmaktadır. NIMBY en basit tarifiyle, bir tesisin gerekli olduğunu kabul etmekle birlikte 
kişilerin yerelliklerinde kurulmasına gösterdiği muhalefeti tanımlamaktadır (Kılıç vd., 20I7; Swofford ve Slattery, 20l0). Genellikle, altyapı ve enerji projelerinde görülmektedir. Rüzgâr çiftliklerine karşı NIMBY tutumu toplumun gösterdiği genel destek ile yereldeki aktif direnç farkı olarak tanımlanmaktadır (Devine-Wright, 2005; Kraft ve Clary, 1991; Van der Horst, 2007). Bireyler rüzgâr enerjisini fikir düzeyinde desteklerken; yakınlarında gerçekleşmesine karşı olmaktadırlar. Kılıç vd. (20I7) NIMBY tutumunun rüzgâr tesislerinin mekânsal yakınlaşmayla ilişkili olduğunu, ancak yereldeki birey ve topluluk arasındaki beklenti farklılıkları ve maliyetinin paylaşımıyla değiştiğini vurgulamaktadır.

NIMBY tutumu, karmaşık bir yapı ve dinamiğe sahiptir. Yatırım sahipleri, merkezi politikacılar, yerel bürokrasi, sivil toplum temsilcileri, aktörler arası ilişkiler, yerel halk ile iletişim, süreçteki kopukluklar ve bundan kaynaklanan şüphecilik, süreci karşıt harekete dönüştürebilen araçlar olarak görülmektedir. Wolsink (2007) halkın rüzgâr enerjisine karşı tutumunu rüzgâr tesislerine karşı olan tutumundan ayırmaktadır. Aitken (20l0) halkın çoğunluğunun genelde rüzgâr enerjisini kabul ettiğini ancak buna karşı çıkanların görüşlerinin de göz ardı edilmemesi gerektiğini, bu gruplarla güven ilişkisi kurulmasının, bilgi ve deneyimlerine güvenilmesinin çok önemli olduğunu vurgulamaktadır. Bununla birlikte, NIMBY tutumunu, manipüle edici, toplumsal uzlaşmayı zedeleyici, muhalefeti basitleştirici, dar açılı olmakla eleştiren çalışmalar da vardır (Evans vd., 20I I; Wolsink, 2007). NIMBY tutumunun her zaman geçerli olmadığı dahi söylenmektedir. Örneğin, Warren ve Birnie (2009) İskoçya ve İrlanda'da ters bir NIMBY tutumu olduğundan bahsetmekte, öyle ki rüzgâr tesislerini türbinlere yakın yaşayanların, uzak yaşayanlardan daha fazla desteklediğini savunmaktadır. Buna ek olarak, Wolsink'e (2000) göre, NIMBY tutumunu sergileyen sakinlerin muhalefeti yalnızca yakınlık endişelerine dayanmamaktadır.

Toplumsal tutuma odaklanan üçüncü çalışma grubu, toplumun bilgilenmesi ve ekonomik paydadan yararlanması üzerinde durmaktadır. Gype (1995), Hollanda'daki çalışmasında, rüzgârdan enerji üretim projelerinin planlama ve inşaat süreçlerinde toplumun bilgilenmesinin, projelere karşı tutumu iyileştirdiğini göstermektedir. Benzer bir şekilde, Krohn ve Damborg da (1999) Danimarka'daki 12000 nüfuslu ve elektrik tüketiminin \%98'inin rüzgâr enerjisinden karşılandığı Sydthy Belediye'sinde, enerji üretimi konusunda yüksek seviyede bilgi sahibi olan kişilerin, daha az bilgi sahibi olan kişilere göre rüzgâr enerjisiyle ilgili daha olumlu düşündüğünü vurgulamaktadır. Bilgilenme ile insanların en yakın türbine ve türbin sayısına karşı tutumlarının değişmediğini ifade etmektedir. Ayrıca, Sydthy Belediyesi'nde rüzgâr türbinleri, \%58'inin yöre halkının ortak olduğu bir kooperatife aittir. Bu sayede, kooperatif üyeleri evlerinin yakınlarına rüzgâr türbini dikilmesini daha rahat kabul etmektedir. Benzer şekilde, Warren ve McFadyen (20I0),
Slattery vd. (20I3) ve Mulvaney vd. (20I3), çalışmalarında yerel halkın mülkiyetindeki rüzgâr tesislerini daha olumlu tutumla karşıladığını ortaya koymaktadır. Bir projenin sahiplik yapısının halkın benimsemesi üzerinde önemli bir etkisi olduğunu belirten diğer çalışmalar (Haggett ve Toke, 2006; Sonnberger ve Ruddat, 2017), projelerin büyük bir enerji şirketi veya yerel bağlantısı olmayan bir yatırımcıdan ziyade yerel enerji kooperatiflerine ait olduklarında genellikle daha uygun görüldügünü göstermektedir. Sahiplilik yanında, rüzgârdan enerji üretiminin ekonomik katkıları da yerel halkın fayda sağladığı alanlar olarak dile getirilmektedir. Örneğin, Munday vd. (20I I), bu bağlamda, kira getirisi, müteahhitlik hizmetleri, istihdam, yerel topluluklara mali yardımlar, peyzaj geliştirme, yol sunumu, eğitim ziyaretleri gibi konulardan bahsetmektedir. Rüzgârdan enerji üretim tesislerinin çeşitli turizm faaliyetlerinin gelişmesine imkan verdiğini dile getiren çalışmalar da vardır (Aitchison, 2004, 2012; Starling, 2006; Young, 1993).

Toplumsal tutumla ilgili dördüncü grup çalışmada; rüzgârdan enerji üretiminden rahatsız olma durumunun bireyin bakış açısından nasıl etkilendiği araştırılmaktadır. Bu çalışmalarda, demografik yapı, eğitim, gelir ve iş durumu, ideolojik ve siyasi duruş gibi değişkenlerin bakış açısını nasıl belirlediği üzerinde durulmaktadır (Aitken, 2010; Bishop, 2002; Bishop \& Miller, 2007; Cavallaro \& Ciralo, 2005; Daugarrd, 1997; DevineWright, 2007; Torres-Sibille vd., 2009; Tsoutsos vd., 2009a; Tsoutsos vd., 2009b; Wang vd., 2009; Warren ve McFadyen, 2010). Wolsink and Sprengers (1993) Danimarka, Hollanda ve Almanya'da gürültüden doğan rahatsızlığın sadece birkaç insanı etkilediğini, etkilenenlerin rahatsızlığının da gerçek gürültü seviyesi ile değil, rüzgâr türbinlerine olan olumsuz düşünceler ile ilişkili olduğunu iddia etmektedir. Simon (1996) İngiltere'de rüzgâr enerjisine olumlu ve olumsuz bakan bireylerin ileri sürdükleri noktaları özetlemektedir. Buna göre; olumlu düşünen bireyler, yenilenebilir enerjinin diğer enerji kaynaklarına alternatif olduğuna, çevreyi kirletmediğine, kısıtlı olmadığına, iklim değişikliği bağlamında ciddiye alınması gerektiğine vurgu yapmaktadır. Olumsuz düşünen bireyler ise, rüzgâr enerjisinin enerji problemlerini çözemeyeceği, pahalı olduğu, türbinlerin güvenilir olmadığı, gürültülü olduğu ve manzarayı bozduğu yönünde görüş sunmaktadır. Buna paralel olarak, Wolsink (1988) türbinlerin manzarayı güzelleştirmesinin veya bozmasının zevke bağlı olduğunu, rüzgâr enerjisinin fiyatının pahalı veya ucuz olmasının ise bireylerin küresel iklime verdiği değere ve sera etkisi kuramına inanıp inanmamasına bağlı olduğunu vurgulamaktadır.

Krohn ve Damborg (1999) cinsiyetin tercihlere etkisini gösterdiği çalışmasında, kadınların iki ilâ sekiz türbinden oluşan rüzgâr tesislerini sekizden daha fazla türbini olan rüzgâr tesislerine ve tek başına dikili olan türbine tercih ettiklerini göstermektedir. Buna karşılık, erkekler 10 ilâ 50 türbinlik tesisleri tercih etmekte ve türbinleri kadınlara göre daha gü- 
rültülü bulmaktadır. Yine aynı çalışmada bahsedilen ve Yuan ve Huisingh'in (20I5) desteklediği bir başka konu eğitimli, yüksek gelirli ve 40 yaşın üzerindeki kişilerin rüzgâr enerji üretimini destekleme eğiliminde olmasıdır. 60 yaşın üzerindeki kişiler diğer yaş gruplarına göre rüzgâr türbinlerine daha eleştirel, isteksiz ve muhafazakar bakmaktadır. Politik tercihler de düşük karbon teknolojilerinin sosyal kabulünü ve politik partilerin bu yöndeki yatırım taahhütlerini etkilemektedir (DevineWright, 2007). Harper vd.'nin (2019) İngiltere'den verdiği örneğe göre, 20I5'teki genel seçimlerde, yenilenebilir enerji gelişimini İşçi ve Liberal Demokrat Parti destekçilerinin \%85'ten fazlası desteklerken, Muhafazakar Parti (MP) destekçilerinin yalnızca \%62'sinin desteklemesi üzerine MP'nin rüzgar karşıtı bir duruş sergilediği bilinmektedir.

\subsection{Sosyo-Mekânsal Duyarlılıklar ve Değişkenleri}

Yukarıda bahsedilen çalışmalar; öznel veya toplumsal değişkenlere göre farklılaşan, kişilerin ve toplulukların rüzgârdan enerji üretimine karşı geliştirdikleri bir tutum veya tepkiyi ortaya koymaktadır. Bu, toplumların rüzgârdan enerji üretiminden belli alanlarda duyarlılık geliştirerek etkilendiklerini gündeme getirmektedir. Yurtdışında yapılan çalışmalara bakıldığında, rüzgâr tesislerinin etkisinin toplumsal olarak doğrudan mekânsal bir ilişki üzerinden hissedildiği dört temel duyarlılık alanı olduğu gözlemlenmektedir. Bunlar çevresel, ekonomik, duyusal ve teknolojik alanlardır.

Birinci olarak; rüzgârdan enerji üretirken orman, sulak alan, su kaynakları, havza, kuş göç yolları gibi doğal alanları etkilemesinden kaynaklı bir hassasiyetin geliştiğine birçok kaynak tarafından dikkat çekilmektedir (Cavallaro ve Ciralo, 2005; Drewitt vd., 2006; Kaya \& Kahraman, 2010; NWCC, 1999; Telleria 2009; Wang vd., 2009). Bu kapsamda, rüzgârdan enerji üretim sahası içerisinde veya yakınlarındaki ekolojik alanlarda bentik kaynakların, su ürünlerinin, deniz hayatının ve ormana dayalı türlerin değiştiği; ve vahşi hayatın beslenme bölgelerinden uzaklaştıkları gözlemlenmektedir (Aydın vd., 20।3; Baban ve Parry, 200I; EEA, 2009; Haugen, 20I I; IFC ve WBG, 2007; IPCC, 20I2; NIA, 20I3; Yue ve Wang, 2006). Ayrıca, kuş ve yarasaların türbinlere çarpıp öldükleri, kuşların göç esnasında uçma yönlerini türbinlerin görsel, gürültü ve titreşim etkileri sonucunda değiştirdiği vurgulanmaktadır (Aydın vd., 2013; Clarke, 199I; Dai vd., 2015; Haugen, 20II; IFC ve WBG, 2007; Klepinger, 2007; Premalatha vd, 20I4; Pearce-Higgins vd, 2012; Schaub, 2012; US EPA, 2013; Toja-Silva vd, 2013; Zahedi, 20I2). Doğal çevrenin yanında, tarihsel ve kültürel miras alanlarının da rüzgâr türbinlerinden etkilendiği bir grup araştırmacı tarafından ortaya konmaktadır (Haugen, 20ll; Tertra Tech EC Inc. vd. 2008).

İkinci grup çalışmalar; rüzgârdan enerji üretiminin yerel halkın ekonomik faaliyetleri üzerindeki etkilerini değerlendirmek- tedir. Kılıç vd. (20I7) rüzgâr tesislerinin kurulum aşamasında gerçekleşen inşaat ve nakliye gibi işlerin ormancılık, hayvancılık ve çiftçilik faaliyetlerinin yürütüldüğü orman, mera ve tarım alanlarında tahribat yarattığını, kurulum sonrasında tesisler söz konusu alanlarda bölünmeye neden olduğu için ekonomik faaliyetleri azalttığını vurgulamaktadır. Bunu Mikolajczak vd.'nin (2013) rüzgâr tesislerinin kazlar üzerindeki etkilerine yönelik yaptığı çalışma desteklemektedir. Türbinlere 50 ve 500 metre yakınlıkta kurulan kümeslerde kazların ağılıklarının düştüğü, bağışıklık sisteminin kandaki etkinliğini azaltan kortisol hormon seviyesinin artığı ve davranışlarının bozulduğu gözlemlenmektedir.

Üçüncü grup çalışmalar; duyusal konularla ilgili ortaya çıkan duyarlılıkları ve sağlık sorunlarını irdelemektedir. Bu duyarlılıklar, estetik ve ışık/gölge etkileri olarak ayrışmaktadır. Çalışmalar hem deniz hem de kara tipi santrallerin estetik açıdan "güzel” gözükmediğini vurgulamakta (Haugen, 20I I; Baban ve Parry, 200I; Bishop ve Miller, 2007; Daugarrd, 1997; Nguyen, 2007; Premalatha vd., 20I4; Voivontas vd., 1998; Zahedi, 20I2); buna ek olarak, santrallerin ışık ve gölge titreşiminin (Haugen, 20ll; Klepinger, 2007; Kılıç vd., 2017; Lima vd, 20।3; Premalatha vd, 20I4) yakın çevrede yaşayan halkın yaşam kalitesini ve sağlığını bozacak düzeyde olduğunu göstermektedir. Santrallerin gürültüsünün benzer etkiler yarattığı da söylenmektedir (Bishop ve Proctor, 1994; Yue ve Wang, 2006; Tester vd., 2005; Aydın vd., 2013; Ramirez-Rosado vd., 2008; Bakker vd., 2012; Haugen, 20I I; Toja-Silva vd., 20I3). Bununla birlikte, rüzgâr türbinlerinin Rüzgâr Enerjisi Sendromu (Pierpont, 2009) olarak adlandırılan uyku bozukluğu, baş ağrısı ve dönmesi, bulantı, kulakta çınlama ve basınç, kalp çarpıntısı ve asabiyet, konsantrasyon bozukluğu ve hafıza kaybı gibi belirtilere yol açtığı iddia edilmektedir.

Son grup çalışmalar, teknolojik konuları irdelemektedir. Bunlar, uçak iniş ve kalkış koridorlarındaki güvenlik, yollar, demiryolları ve radyo iletişim merkezlerindeki sinyaller ve radar sistemleri ile enerji nakil hatları gibi konulardır (Burleson, 2009; Toja-Silva vd., 2013; Haugen, 20I I; Tetra Tech EC Inc. vd., 2008). Rüzgâr türbin kanatları; yansıma, soğurma ve dağıtma yoluyla elektromanyetik alanları periyodik modülasyona uğratarak TV ve radyo alıcılarını etkileyebilmektedir (Toja-Silva vd., 20I3). Haugen'in (20ll) çekme mesafeleri açısından uluslararası rüzgâr enerji yatırımlarını incelediği rapora göre, Danimarka'da uçuş güvenliği açısından, boyutu $150 \mathrm{~m}$ üzerinde olan rüzgâr türbinlerinin ve hava alanlarının çevresinde ve uçakların uçuş koridoru yakınında yer alan 100 m üzerindeki rüzgâr türbinlerinin ışıklandırılması gerekmektedir. Aynı raporda, güvenlik gerekçesiyle, farklı ülkelerde rüzgâr türbinlerinin yollardan, demiryollarından, telsiz iletişiminden ve güç hatlarından 50-120 m arasında değişen mesafelerde konumlandırılması gerektiği belirtilmektedir. 
Bu çalışmalar doğrultusunda, rüzgâr tesislerinin yer seçiminde dünyada kullanılan ölçütler ile Türkiye'dekiler karşılaştırıldığında, Türkiye'de bu konuda önemli yetersizlikler olduğu ortaya çıkmaktadır. Özellikle, rüzgâr türbinlerinin yerleşim alanlarına ne kadar yaklaşabileceği ile ilgili yasal bir yaptırımın bulunmamasının, Türkiye'deki yerel direnci tetiklediği varsayılabilir. Ayrıca, rüzgâr tesisleri doğal, kültürel ve sosyo-ekonomik faaliyet alanlarına oldukça yakın yer seçebilmektedir. Bu konuda, Yetiş vd. (20I5) tarafından hazırlanan "Rüzgâr Enerjisi Santralleri Raporu" çevresel, sosyo-ekonomik ve yaşam alanları açısından dünyadaki ve Türkiye'deki yer seçim mesafelerini değerlendirmekte ve bu yetersizliği göstermektedir. Buna göre, dünyadaki mevzuatlar uyarınca, rüzgâr tesisleri yerleşimlerden minimum $300 \mathrm{~m}$ ile $2000 \mathrm{~m}$ arasında değişen bir uzaklıkta yer seçebilmektedir. Ülkemizde böyle bir kısıtlama yoktur. Ayrıca, dünyada rüzgâr tesisleri orman alanlarına minimum 200 m ile 500 $\mathrm{m}$ arasında uzaklıkta yer seçebiliyor iken, Türkiye'de, kesilen ağaçların bedeli yatırımcı tarafından ödendiği sürece orman alanına tesis kurulabilmektedir. Diğer ülkelerde rüzgâr tesisleri ekolojik olarak değerli alanlardan 200 m ile 1000 m arasında değişen uzaklıklara kurulabiliyorken, Türkiye'de tesislerin kesin korunacak hassas doğal sit alanlarına en az 300 m mesafede kurulmasına, nitelikli ve sürdürülebilir koruma ve kontrollü kullanım alanlarında faaliyetlerine kontrollü bir şekilde devam etmesine izin verilmektedir. Milli ve Doğal Parklarda, Özel Çevre Koruma Bölgelerinde, Doğal Yaşamı Geliştirme alanlarında ilgili kurumun görüşü üzerine tesisler yer alabilmektedir. Ayrıca, diğer ülkelerde rüzgâr tesisleri denizden $3 \mathrm{~km}$ uzakta yer seçebiliyorken Türkiye'de göller ve akarsulara 300 m, deniz kıyısına ise $100 \mathrm{~m}$ uzaklık koşulu koyulmaktadır. Rüzgâr tesisleri kültürel miras alanlarına dünyada 1000 m uzakta kurulabilirken ülkemizde birinci ve ikinci derece kültürel miras sit alanlarında rüzgâr tesislerine izin verilmemektedir. Tarım alanlarında ise, Türkiye'de Toprak Koruma Komisyonu'ndan alınacak izne bağlı olarak kurulabilmektedir.

\section{Duyarlılıklara Derinlemesine Bakmak}

Bu makalede sunulan araştırmanın yöntemsel çerçevesi dört temel varsayım üzerine kuruludur. Birincisi, teknolojik gelişime odaklı rüzgâr enerji üretim süreci toplumsal deneyimleri ve algıyı etkilemektedir. Bu üretim süreci, toplumsal açıdan anlaşılmalıdır. Buna dayanarak, araştırma, toplumun duyarlı olduğu alanları toplumun deneyimi ve algısı üzerinden anlamaya yönelik kurgulanmıştır. İkincisi, rüzgâr enerjisi üretim sürecinin toplumsal etkileri farklı yerelliklere göre değişmektedir. Buna göre, çalışma için rüzgâr enerjisi üretim sürecinde Türkiye'de halkın rüzgâr enerji tesislerine en fazla tepki gösterdiği il olarak İzmir seçilmiştir. Üçüncüsü, birinci ve ikinci varsayımın birbiriyle olan ilişkisi üzerine kuruludur. Deneyimler ve yerel özellikler kolektif algıyı değiştirmektedir. Örgütlenme düzeyi ve aktif yurttaşlık kapasitesi yüksek bir toplumda duyarlılık seviyesi ve bunu ifade etme kapasitesi de yükselmektedir. Dör- düncüsü, toplumun duyarlılığı doğal ve insan yaşam alanları çevresinde yer seçen rüzgâr tesislerinin büyüklüğüne ve bu alanlara yakınlığına bağlı olarak değişkenlik gösterebilmektedir.

$\mathrm{Bu}$ varsayımlar dikkate alınarak; çalışmanın temel amacı, Türkiye'nin rüzgâr tesislerinin yoğun olarak yer seçtiği, aktif yurttaşlık kapasitesi yüksek (Ataöv ve Eraydın, 20l I; Eraydin, 2009; Eraydin, Kok ve Vranken, 2010) ve rüzgâr tesislerine toplumun en fazla tepki gösterdiği İzmir'de, rüzgârdan enerji üretiminin duyarlılık yarattığı alanların tespit edilmesi ve önceliklendirilmesi olarak tarif edilmektedir. Ayrıca, bu çalışma kapsamında, bundan sonraki adımlara yol gösterici olması bakımından rüzgârdan enerji üretim sürecinde ortaya çıkabilecek sorunlara çözüm önerileri de problemi yaşayanların gözüyle araştırılmaktadır. Buna göre, çalışma, iki temel araştırma sorusunu cevaplamaya yönelik tasarlanmıştır: (i) İzmir'de rüzgârdan enerji üretiminin sosyo-mekânsal duyarlılık alanları nelerdir?; (ii) İzmir'de rüzgârdan enerji üretim sürecinin olumsuz etkilerine yaşayanların çözüm önerileri nelerdir?

Bu soruları cevaplamak için, yöntemsel olarak Keşifsel Araştırma (Exploratory Research) yaklaşımı benimsenmiştir. Bu yaklaşımın benimsenmesinin en temel gerekçesi rüzgârdan enerji üretiminin çevresel, ekonomik, duyusal ve teknolojik etki alanlarına ilişkin toplumda oluşan duyarlılık konularının Türkiye özelinde yeterince araştırılmamış olmasıdır. Çalışma betimleyici bir araştırma olarak yürütülmüş, toplumun duyarlı olduğu konular yaşayanların ifade ettiği şekilde açık uçlu sorular üzerinden toplanmıştır. Daha önce toplumsal duyarlılık alanları ile ilgili yurtdışında yürütülen çalışmaların tematik bulguları ve yerel yönetim ve sivil inisiyatiflerle yapılan ön görüşmeler sonucu, doğal yaşam, tarım, hayvancılık, görüntü, gürültü, sağlık, manyetik alan ve türbin sayısından oluşan genel duyarlılık alanları açık uçlu soruları yönlendirmesi için kullanılmıştır. Ayrıca, yaşayanların duyarlı olduğu alanların önceliklendirilmesinin yapılabilmesi için araştırmaya katılanlardan bu genel duyarlılık alanlarını Likert ölçeği (I “hiç”ten 7 “çok”a kadar değişen 7 ölçekli) kullanarak derecelendirmeleri istenmiştir. Buna göre, çalışma, ağırııklı olarak nitel verilerin nicel verilerle desteklendiği betimleyici bilginin sayısallaştırılıp analiz edildiği bir yöntemsel çerçeveye sahiptir. Veri toplama tekniği olarak Derinlemesine Mülakat uygulanırken toplanan nitel veri her bir duyarlılık alanı için verilen ifadeler Tematik Analiz tekniği ile kavram grupları altında sistematikleştirilmiş, ifadelerden çıkan kavramların söylenme sıklığı ve yüzdeleri hesaplanmıştır. Likert ölçekli değerlendirmeler ise Basit İstatistiki Hesaplamalar yoluyla analiz edilmiştir. Mülakat metinlerindeki nitel kavramların söylenme sıklığı, yüzdeleri ve niceliksel değerlendirme ortalamaları tablolar halinde sunulmaktadır.

Yerel yönetim ve sivil inisiyatif temsilcileri ile yapılan ön görüşmelerde rüzgâr tesislerinden etkilenen yerleşimlerle de ilgili bilgiler alınmış ve bu yerleşimler saha çalışması kapsamına 
Tablo I. Saha çalışması yerleşimleri, en yakın rüzgâr tesisi uzaklığı, toplam gücü ve türbin sayısı

\begin{tabular}{lccccc}
\hline İlçe & Yerleşim & Tesis adı & Uzaklık & Toplam güç (MW) & Türbin sayısı \\
\hline Çeşme & Ovacık & Çeşme & $0-500 \mathrm{~m}$ & 18 & 6 \\
Çeşme & Karaköy & Mazı-I & $0-500 \mathrm{~m}$ & 56,2 & 56 \\
Karaburun & Yaylaköy & Karaburun & $0-500 \mathrm{~m}$ & 223 & 50 \\
Alaçatı & Germiyan & Germiyan & $500 \mathrm{~m}-1 \mathrm{~km}$ & 10,7 & 7 \\
Foça & Kozbeyli & Kozbeyli & $500 \mathrm{~m}-1 \mathrm{~km}$ & 32,2 & 14 \\
Urla & Zeytineli & Zeytineli & $500 \mathrm{~m}-1 \mathrm{~km}$ & 49,5 & 20 \\
Bergama & Atçılar & Aliağa & $500 \mathrm{~m}-I \mathrm{~km}$ & 120 & 46 \\
Karaburun & Mordoğan & Mordoğan & $1 \mathrm{~km}+$ & 42 & 15 \\
\hline
\end{tabular}

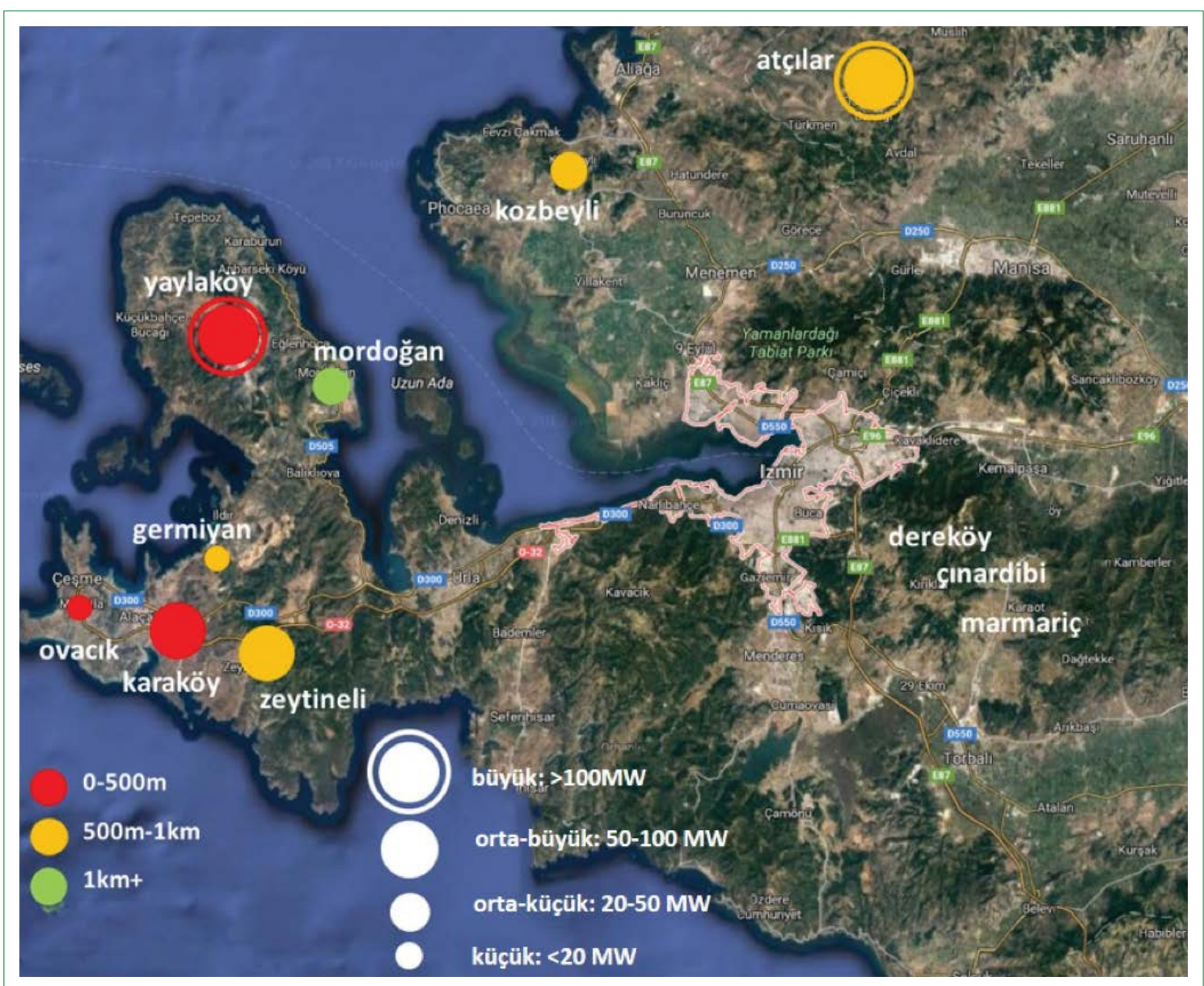

Şekil 2. Saha çalışması yerleşimleri, en yakın rüzgâr tesisi toplam gücü ve yerleşimlere uzakııkları .

dahil edilmiştir. Buna göre, İzmir'de, saha araştırması yapılan yerleşimlerin seçiminde, ön görüşmelerden gelen öneriler mevcut yazınla bütünleştirilmiş (Krohn and Damborg, 1999; Simon, 1996), tesis enerji üretim kapasitesi, türbin sayısı ve yakınlığı dikkate alınarak taslak bir yerleşim listesi yapılmış, toplumsal tepkilerin yoğunlaştığı yerleşimler bu listeye eklenerek son haline getirilmiştir. Bununla birlikte, araştırma sürecinde tesisler için yan yana yer seçilmesinden kaynaklı kümülatif bir etkinin oluştuğu anlaşılmıştır. Buna referansla, tesisler hangi büyüklükte olursa olsun yerleşimin çevresinde yer seçmiş ise toplumsal bir duyarlılığın ortaya çıkacağı kabulü de gelişmiştir. Saha çalışması, araştırmanın yürütüldüğü 2016 yılında mevcut olan toplam 22 rüzgâr tesisinden farklı büyüklükteki (I20 MW; 60-50 MW; 25-40 MW; <20 MW) tesislere farklı yakınlıklarda (0-500 m; $500 \mathrm{~m}-\mathrm{l} \mathrm{km;} \mathrm{I} \mathrm{km+)}$ olan 8 yerleşimde yapılmıştır (Tablo I, Şekil 2). 
Tablo 2. Rüzgârdan enerji üretiminin doğal çevre ve ekonomik yaşamda yarattığı duyarlılık alanları ile ilgili kavramlar ve söylenme sıklık yüzdeleri

\begin{tabular}{|c|c|c|c|c|c|}
\hline Doğal yaşam & $\%$ & Tarım & $\%$ & Hayvancılık & $\%$ \\
\hline Hayvanlar & 24,2 & Mahsüllerin azalması, bitkilerin kuruması & 25,3 & Kümes, küçük ve büyükbaş hayvanlar & 17,6 \\
\hline Flora & 15,8 & Tarımsal faaliyetler & $21, I$ & Meraların daralması & 20,8 \\
\hline Toprak verimliliği & 10,8 & Doğal yaşam ve iklim & 9,5 & Arıcılığın yok olması & 12,8 \\
\hline İnsan & 10,8 & Radyasyon yaratma & 3,2 & Yaban hayat hayvanları & $\mathrm{II}, 2$ \\
\hline Doğal Kaynaklar & 9,2 & Büyük tarım arazilerinin yok olması & 3,2 & Kuraklık & 8 \\
\hline Etkisi yok & 9,2 & Etkisi yok & 23,2 & Etkisi yok & 18,4 \\
\hline $\begin{array}{l}\text { Başkalarından duyduğuna } \\
\text { dayanarak: doğal yaşama } \\
\text { "olumsuz” etki }\end{array}$ & 20,2 & $\begin{array}{l}\text { Başkalarından duyduğuna dayanarak } \\
\text { toprağa "olumsuz" etki }\end{array}$ & 16,5 & $\begin{array}{l}\text { Başkalarından duyduğuna dayanarak: } \\
\text { hayvancılığa "olumsuz" etki }\end{array}$ & $\mathrm{II}, 2$ \\
\hline Toplam & 100 & Toplam & 100 & Toplam & 100 \\
\hline
\end{tabular}

Çalışmanın yürütüldüğü her bir yerleşimde, birer muhtar ve onun yönlendirdiği hane halklarını içeren bir örneklem seçilmiş, bunun için de Kar Topu Yöntemi kullanılmıştır. Derinlemesine görüşme yapılan kişilerin her yerleşimde benzer sayıda kadın ve erkekten, benzer yaş aralıklarından (18-24; $25-60 ; 60+)$ ve her yerleşimden 25 ile 30 arasında değişen bir sayıda olması öngörülmüştür. Ancak saha çalışması sırasında gözlemlenen ve araştırma kapsamında iletişime geçilen sivil inisiyatiflerin belirttiği üzere İzmir'in rüzgâr üretimine doymuşluğu, rüzgârdan enerji üretiminin geliştirilmesi ile ilgili her türlü çalışmaya karşı yoğun tepkisi ve bununla ilişkili olarak araştırmaya katılmama tercihleri nedeniyle yerleşim özelinde örneklem sayısı 3 ile 35 kişi arasında değişmiştir. Buna göre, Ovacık'ta 35, Kozbeyli'de 30, Zeytineli'de 26, Germiyan'da 25, Yaylaköy'de 19, Atçılar'da 17, Mordoğan'da 8, Karaköy'de 3 olmak üzere, 82 kadın $(\% 50,3)$ ve 81 erkek $(\% 49,7)$ toplam 163 kişi ile görüşülmüştür. Katılımcıların yarıdan fazlası 26-65 yaş aralığında (\%55), dörtte biri 65 yaş üzeri (\%24) ve beşte biri 18-25 yaş aralığındadır (\%20.5). Çalışmaya katılanların yarıdan fazlası yerli (\%58), diğer katılımcılar sonradan yerleşmiş (\%36) veya ikinci konut sahibidir (\%6). Katılımcıların yarısı ilkokul mezunu (\%56), üçte biri (\%32.5) ortaokul ve lise mezunudur. Onda bire yakın oranı da üniversite mezunudur (\%8). Lise ve üniversite mezun sayısı erkek katılımcılarda kadın katılımcılara göre daha yüksektir.

\section{I İzmir'de Rüzgârdan Enerji Üretirken Ortaya Çıkan Sosyo-Mekânsal Duyarlılıklar}

Derinlemesine görüşsmeler doğal yaşam, tarım, hayvancılık, görüntü, gürülttü, sağlık, manyetik alan ve türbin sayısının yerel halk üzerindeki etkilerinin nasıı yaşandı̆̆ı ile ilgili ayrıntılı bilgiyi ve çözüm önerilerini ortaya çıkarmıştır.

Tablo 2 rüzgârdan enerji üretiminin doğal çevre ve ekonomik yaşamla ilişkili toplumun duyarlı olduğu kavramları göstermektedir. Buna göre, katılımcılar doğal yaşam ile ilgili ifade ettikleri tüm kavramların dörtte birini $(\% 24,2)$ rüzgâr çiftliklerinin hayvanlara olan etkisi ile açıklamaktadır. Dile getirilen tüm kavramların diğer dörtte birlik kısmı tesislerin floraya $(\% \mid 5,8)$ ve toprağın verimliliğine $(\% \mid 0,8)$ olan olumsuz etkisi üzerinedir. Kavramların beşte biri ise, rüzgâr tesislerinin insan $(\% \mid 0,8)$ ve doğal kaynaklar $(\% 9,2)$ üzerindeki olumsuz etkisinden bahsetmekte, onda birlik bir kısım $(\% 9,2)$ etkinin olmadığını söylemektedir.

Rüzgâr tesislerinin tarımsal faaliyetlere etkisi ile ilgili olarak, çalışmaya katılanların ifadelerinin yarııına yakını mahsullerin azalmasına, bitkilerin yok olmasına, kurumasına $(\% 25,3)$ ve tarımsal faaliyetlerin olumsuz etkilenmesine $(\% 2 I, I)$ işaret etmektedir. Dörtte birlik bir kısım ise, rüzgâr tesislerinin tarımsal faaliyetler üzerinde etkisi olmadığını $(\% 23,2)$ belirtmektedir. Hayvancılık ile ilgili değerlendirmelerin beşte biri meraların daralması $(\% 20,8)$, yarısı rüzgâr tesislerinin kümes hayvanları ile küçük ve büyük baş hayvanlarda gözlemlenen sorunlar $(\% \mid 7,6)$, arıcilık ve arıların yok olması $(\% \mid 2,8)$ ile yaban hayvanlarının azalması ve yok olması $(\% 11,2)$ hakkındadır. Değerlendirmelerin yaklaşık beşte biri $(\% \mid 8,4)$ ise rüzgâr tesislerinin hayvancılığa etkisinin olmadığı yönündedir.

Bununla birlikte, başkalarından duyulması üzerine rüzgâr çiftliklerinin olumsuz etkileri olduğunun ifade edilme sıklı̆ı doğal yaşam ile ilgili tüm ifadelerin \%20'sini, tarım faaliyetleri ile ilgili ifadelerin \% 16,5'ini, hayvancılık için ise \% I'ini kapsamaktadır.

Tablo 3, rüzgârdan enerji üretiminin bireylerin görme ve işitme duyuları yoluyla doğrudan algılanabilecek konuları ve genel olarak sağıık alanı ile ilişkili duyarlılık kavramlarını göstermektedir. Buna göre, rüzgâr tesislerinin görüntü bütünlüğüne etkisi konusunda çalışmaya katılanların ifade ettikleri tüm kavramların yaklaşık dörtte üçünün (\%72) görsel bir memnuniyetsizlik ile ilişkili olduğu gözlemlenmektedir. Bu ifadelerin üçte birinden fazlasını (\%38) rüzgâr çiftliklerinin doğal manzarayı bozması; yaklaşık dörtte birlik bir kısmını $(\% 23,3)$ türbin- 
Tablo 3. Rüzgârdan enerji üretiminin duyusal olarak ve sağlıkta yarattığı duyarlılık alanları ile ilgili kavramlar ve söylenme sıklık yüzdeleri

\begin{tabular}{|c|c|c|c|c|c|}
\hline Görüntü & $\%$ & Gürültü & $\%$ & Sağlık & $\%$ \\
\hline Doğal manzara & 38 & Çok rüzgârda artması & 20,1 & $\begin{array}{l}\text { Rahatsızlıklar (baş ağrısı, stres, kulak } \\
\text { ağrısı, vertigo, kalp çarpıntısı, göz } \\
\text { bulanıklığı, uykusuzluk, grip, kanser) }\end{array}$ & 48,9 \\
\hline Rahatsız olunmaması & 23,3 & Gürültünün çokluğu & 19,4 & Etkisi yok & 12,2 \\
\hline $\begin{array}{l}\text { Türbinin fiziksel } \\
\text { özelliklerinden } \\
\text { rahatsızlık (konum, sayı, } \\
\text { boyut, gölge) }\end{array}$ & 21,7 & $\begin{array}{l}\text { Türbinin fiziksel özelliklerine göre } \\
\text { artması (mesafe, sayı) }\end{array}$ & 17,9 & Radyasyon & 10 \\
\hline Görüntüden rahatsızlık & 10,9 & Akşam/Sessizlikte artması & 17,9 & Hastalıkların artması & 8,9 \\
\hline \multirow[t]{3}{*}{ Kabullenme } & 6,2 & Rahatsız etmemesi/alışma & 15,7 & Fikri yok & 3,3 \\
\hline & & Sağ|ığı olumsuz etkilemesi & 4,5 & Türbin mesafesine göre artması & 2,2 \\
\hline & & $\begin{array}{l}\text { Başkalarından duyduğuna dayanarak: } \\
\text { "olumsuz" etki }\end{array}$ & 4,5 & $\begin{array}{l}\text { Başkalarından duyduğuna dayanarak: } \\
\text { "olumsuz" etki }\end{array}$ & 14,4 \\
\hline Toplam & 100 & Toplam & 100 & Toplam & 100 \\
\hline
\end{tabular}

lerin fiziksel özelliklerinden rahatsızlık duyulması; onda birini de $(\% \mid 0,9)$ genel olarak görüntünün beğenilmemesi oluşturmaktadır. Görüntü bütünlüğü ile ilişkili tüm ifadelerin üçte birlik kısmı ise çiftliklerden rahatsızlık duyulmadı̆̆ını $(\% 23,3)$ ve görüntünün kabullenildiğini $(\% 6,2)$ işaret etmektedir.

Rüzgâr tesislerinin gürültüye etkisi konusunda ifade edilen tüm kavramların beşte biri \%20,I) sert rüzgârlı günlerde gürültünün artması ile ilişkilenmektedir. Bunun yanı sıra, benzer oranlarla ifade edilen tüm kavramların yarısından fazlası gürültünün çokluğunu $(\% \mid 9,4)$, gürültünün akşam, gece ve sessizlikte çok olmasını $(\% \mid 7,9)$, bunun mesafeye ve türbin sayısına göre değişmesini $(\%$ I7,9) ve sağlığa olumsuz etkisini $(\% 4,5)$ içermektedir. İfade edilen kavramların kalan beşte birlik kısmında ise gürültünün rahatsız etmemesi ve gürültüye alışma (\%।5,7) dile getirilmektedir.

Rüzgâr tesislerinin çeşitli hastalıklarla ilişkilendirilmesi tüm ifadelerin yarısını $(\% 48,9)$ oluşturmaktadır. Bu kapsamda, baş ve kulak ağrısı, vertigo, stres, kalp çarpıntısı, göz bulanıklığı, uykusuzluk ve kanser gibi rahatsızlıklardan bahsedilmektedir. Araştırmaya katılanların ifadelerinin beşte biri radyasyon (\%।0) ve hastalıkların artışıyla $(\% 8,9)$ ilişkili iken; onda biri $(\% \mid 2,2)$ rüzgâr tesislerinin herhangi bir hastalıkla ilişkili olmadığını tarif etmektedir.

Başkalarından duyulması üzerine rüzgâr tesislerinin gürültü $(\% 4,5)$ ve sağlık $(\% \mid 4,4)$ konuları açısından olumsuz etkileri olduğu ifade edilirken; tesislerin görüntüsü ile ilgili olarak tüm katılımcıların kendi görüşlerini dile getirdiği gözlemlenmektedir.

Tablo 4, rüzgârdan enerji üretiminin manyetik alan yaratması ve türbin sayısının etkisi ile ilişkili konuları göstermekte- dir. Buna göre, manyetik alan oluşumu ile ilgili ifade edilen kavramların üçte birinden fazlası $(\% 39,2)$ manyetik alanın şebeke, uçak, sağlık ve doğaya etkisi üzerinedir. İfade edilen kavramların dörtte biri, rüzgâr tesislerinin manyetik alan etkisinin olmadığını $(\% \mid 7,4)$ veya böyle bir etkinin bilinmediği $(\% 6,5)$ ile ilgilidir. Kalan üçte birlik kısımda, tesislerin manyetik alan oluşumuna mutlaka etkisinin olduğu $(\% \mid 7,4)$ ve türbin mesafesine göre manyetik alan yaratma etkisi olduğu (\%।3) vurgulanmaktadır. Bunu tesislerdeki türbin sayısının etkisi konusunda dile getirilen ifadeler desteklemektedir. İzlenebileceği gibi, ifadelerin yarısına yakınında $(\% 43,5)$ türbin sayısı arttıkça gürültü ve görüntü gibi etkilerin de arttığı vurgulanmaktadır. İfadelerin yaklaşık onda biri ise $(\% 6,5)$ rüzgâr tesislerinin manyetik alan yaratma etkisinin başkalarından duyulan bir konu olduğuna işaret etmektedir.

Çalışma kapsamında elde edilen betimleyici bulgular yanında, yerel halkın yaşam çevrelerindeki rüzgâr tesislerine yönelik tercihleri ve tesislerin önceki çalışmalarda vurgulanan çevresel, ekonomik, duyusal ve teknolojik etkilerinin toplumda yarattığı duyarlılık derecelendirmeleri Likert ortalamaları ile Tablo 5'te sunulmaktadır. Bu doğrultuda, araştırmaya katılanların yaşam çevrelerinde rüzgâr tesisi bulunması tercihleri yakın mesafeden uzak mesafeye doğru "tercih etmiyorum"dan (0-500 m: Likert ortalaması 2.9) "fazla tercih etmiyorum"a (500 m-I km: Likert ortalaması 3.2) doğru azalmakta ve I km'nin dışında (Likert ortalaması 4.0) olduğunda "farketmez" eğilimine geçmektedir.

Benzer şekilde, rüzgâr tesisleri yerleşimlerden uzaklaştıkça, duyarlılık alanları genel olarak "etkiliyor"dan "farketmez"e doğru düşer şekilde derecelenmektedir. Ancak yerleşimlerin konum özelliklerine ve toplumsal tepkinin yoğunlaştığı yerleşimlere 
Tablo 4. Rüzgârdan enerji üretiminin manyetik alan ve türbin sayısı ile ilişkili yarattığı duyarlılık alanları ile ilgili kavramlar ve söylenme sıklık yüzdeleri

\begin{tabular}{lclr}
\hline Manyetik alan & $\%$ & Türbin sayısı & $\%$ \\
\hline Şebeke, uçak, sağlık ve doğaya etkisi & 39,2 & Türbin sayısının artması ile etkisinin artması & 43,5 \\
Etkisi yok & 17,4 & Etkisi yok & 21,7 \\
Mutlaka etkisinin olması & 17,4 & Hiç olmasın & 10,9 \\
Türbin mesafesine göre manyetik alan yaratma etkisi & 13 & Daha az olsun & 10,9 \\
Fikri yok & 6,5 & Her köyde yeteri kadar olsun & 8,7 \\
Başkalarından duyduğuna dayanarak: "olumsuz" manyetik alan etkisi & 6,5 & Yakında olmasın & 4,3 \\
Toplam & 100 & Toplam & 100
\end{tabular}

Tablo 5. Rüzgâr tesis uzaklığına göre yakın çevrelerinde rüzgâr tesisi tercihi ve duyarlılık alan derecelendirmesi

\begin{tabular}{|c|c|c|c|c|c|c|c|c|c|c|}
\hline Rüzgâr tesis uzaklığı & Konum & $\begin{array}{c}\text { Rüzgâr } \\
\text { tesis } \\
\text { tercihi }\end{array}$ & $\begin{array}{l}\text { Doğal } \\
\text { yaşam }\end{array}$ & Tarım & Hayvancilık & Görüntü & Gürültü & Sağlık & $\begin{array}{l}\text { Manyetik } \\
\text { alan }\end{array}$ & $\begin{array}{l}\text { Türbin } \\
\text { sayısı }\end{array}$ \\
\hline $\begin{array}{l}\text { 0-500 m } \\
\text { (Ovacık, Karaköy, Yaylaköy) }\end{array}$ & $\Delta \circ$ & 2,9 & 5,1 & 3,9 & 3,5 & 4,3 & 4,4 & 3,4 & 2,0 & 4,5 \\
\hline $\begin{array}{l}500 \text { m-I km (Germiyan, } \\
\text { Kozbeyli, Zeytineli, Atçılar) }\end{array}$ & OLA & 3,2 & 4,7 & 4,2 & 4,3 & 3,9 & 5,1 & 4,0 & 4,3 & 5,0 \\
\hline I km + (Mordoğan) & $\Delta$ & 4 & 4,9 & 4,1 & 4,0 & 4,1 & 4,8 & 3,7 & 3,3 & 4,8 \\
\hline
\end{tabular}

(Tercih - Likert Ölçeği: I: "hiç tercih etmiyorum"; 2: "tercih etmiyorum"; 3: "fazla tercih etmiyorum"; 4: "farketmez"; 5 "az tercih ediyorum"; 6: "tercih ediyorum"; 7: "çok tercih ediyorum") (Duyarılık Alanları: I: "hiç etkilemiyor"; 2: "etkilemiyor"; 3: "fazla etkilemiyor"; 4: "farketmez"; 5: "az etkiliyor"; 6: "etkiliyor"; 7: "çok etkiliyor").

$\triangle$ Kıyı Orman $\smile$ Mera $\square$ Sit alanı - Özel çevre koruma alanı

göre duyarlılık derecelenmeleri değişmektedir. Örneğin, farklı uzaklıktaki tüm yerleşimlerde genel olarak tesislerin doğal yaşama etkisine duyarlılık yüksek olmakla birlikte (I km: Likert ortalaması 4.9; $500 \mathrm{~m}-\mathrm{l}$ km: Likert ortalaması 4.9; 0-500 m: Likert ortalaması 5.I), doğal sit alanlarındaki yerleşimlerde bu duyarlılık daha yüksektir (Likert ortalaması 5.I). Tesislere 500 $\mathrm{m}-\mathrm{l} \mathrm{km}$ arasında uzakta olan meraların yakınındaki yerleşimlerde ise, rüzgâr tesislerinin hayvancılık faaliyetlerine etkisine duyarlılık, hayvancılık faaliyetlerinin olmadığı ancak rüzgâr tesislerine 500 m'den daha yakın yerleşimlere (Likert ortalaması 3.5) göre daha yüksektir (Likert ortalaması 4.3).

Rüzgâr tesislerinin görüntüsüne duyarlılık, tesislere en fazla $500 \mathrm{~m}$ uzaklıkta olan (Likert ortalaması 4.3) yerleşimler ile I km'den daha uzakta olan $(500 \mathrm{~m}-\mathrm{l}$ km: Likert ortalaması 3.9; I km+: Likert ortalaması 4.I) yerleşimler arasında belirgin bir farklılaşma göstermemektedir. Buna karşılık, gürültüye, genel sağı̆ğa ve türbin sayısına duyarlılık tesislere mesafeyle ters orantılı olarak yükselmektedir. Gürültüye duyarlılık değerlendirmelerinin Likert ortalamaları, $500 \mathrm{~m}$ içinde, $500 \mathrm{~m}$ ve I km arasında ve I km'den daha uzakta olan yerleşimlerde sırasıyla $4.4,5.1$ ve 4.8 olmakta; sağlığa olan etkiye duyarlılık sırasıyla $3.4,4.0$ ve 3.7 olarak değişmekte; türbin sayısına duyarlılık sırasıyla $4.5,5.0$ ve 4.8 olarak ortaya çıkmaktadır. Bu değerlendirmeler, rüzgâr tesislerinin I km'ye kadar uzakta olanlarının 500 m uzakta olanlarla benzer hatta bazen daha etkili bir duyarlılık yaratabileceği olasılığını düşündürmektedir. Bununla birlikte, mesafeden bağımsız bu tür farklılaşan değer değişimlerinin ve artışlarının toplumsal tepkinin duyarlılık değerlendirmesini nasıl yönlendirebileceği ileriki çalışmalar için bir araştırma konusu olarak ortaya çıkmaktadır.

Çalışma, doğal çevre, ekonomik yaşam, duyularla ilişkili olarak sağıı ve teknoloji konularına değinen toplumsal duyarlılıkların İzmir'de var olduğunu teyit etmekle birlikte bu konuların toplumsal açıdan sorun olmadığını da ortaya koymaktadır. Kendi içinde çelişki içeren bu bulgular, toplumda bir yandan duyarlıIığın olduğunu gösterirken, öte yandan, kişilerin deneyimlemiş olmaktan daha ziyade rüzgâr tesislerinin etkisiyle ilgili kolektif bir duyarlılık algısı olduğunu göstermektedir. Bununla birlikte, etkiyi yaşamıyor olmak toplumsal duyarlılığın geçersizliği anlamına da gelmemektedir.

Tablo 6'da bu çelişkinin temelinin anlaşılmasına ışık tutacak toplumsal duyarlılı̆̆ın giderilmesine yönelik, yaşayanların kendi görüşlerini içeren çözüm önerileri sunulmaktadır. Araştırmada bu konuda toplanan tüm ifadelerin dörtte üçü; halkın katılımına, kamusal faydanın düşünülmesine, türbin sayısının azaltılmasına ve rüzgârdan enerji üretim tesisleri için insan faaliyet alanlarına uzakta yer seçilmesinin gerekliliğine odak- 
Tablo 6. Rüzgârdan enerji üretimi sürecinde ortaya çıkan sosyo-mekânsal duyarlılıklara çözüm önerileri

\begin{tabular}{lc}
\hline Toplumsal sorunlara çözüm önerileri & $\%$ \\
\hline Bilgilendirme, iletişim, halk görüşünün alınması, halkın katılımı & 34,6 \\
Kamusal faydanın düşünülmesi, rahatsız etmeyecek ve zarar vermeyecek şekilde yapma & 20,8 \\
Uzaklık ve türbin sayısı sınırlılı̆ı, yerleşim alanlarına, turizm, hayvancılık ve tarım alanlarına uzaklık & 13,8 \\
Hukuki yollar, eylemler, halkın sesini duyurması & 8 \\
Sorun yok, memleket için yapılıyor & 7,4 \\
Diğer kaynaklara yönelme & 6,4 \\
Birlik olmak & 5,9 \\
Siyasi tutum ve denetim & 3,2 \\
Toplam (söylenme sıklı̆̆ \%) & 100
\end{tabular}

lanmaktadır. Özellikle, ifadelerin üçte biri $(\% 34,6)$ halkın sürece katılımı, bilgilendirilmesi ve görüşünün alınması; beşte biri $(\% 20,8)$ kamusal faydanın düşünülmesi ve tesislerin insan ve doğaya zarar vermeyecek şekilde kurulması ile ilgilidir. Bunu, onda birden fazla bir oran ile $(\% / 3,8)$ türbin sayısının sınırlılı̆ı ve yerleşim alanlarına, turizm, hayvancılık ve tarım alanlarına uzaklık ile ilgili çekme mesafelerinin belirlenmesi konusundaki ifadeler takip etmektedir.

\section{Sonuç}

Çalışma, rüzgâr enerji üretiminin İzmir'de doğal yaşam, tarım, hayvancilık, görüntü, gürültü, sağlık, manyetik alan ve türbin sayısı ile ilgili toplumda bir duyarlılık oluşturduğunu göstermektedir. Bu duyarlılıklar, çoğunluklu olarak yaşanılan sorunlardan ve kolektif algının bu yönde olmasından kaynaklı olarak ortaya çıkmaktadır. Bununla birlikte, rüzgâr enerji üretiminin etkisi olmadığına dair görüşler de vardır. Duyarlılı̆ı içeren veya içermeyen ifadelerin yüzdeleri ne olursa olsun sosyal ve mekânsal etkileri olan rüzgâr enerjisinin gelişimi konusunda toplumda herhangi bir duyarlılık oluştuğunda, bu duyarlıı̆ın gelişim kararlarında muhakkak dikkate alınması gerekliliği açıktır. Bu durum üç konuyu tartışmaya açmaktadır.

Öncelikle, Türkiye bağlamında yürütülmüş olan bu çalışma, özellikle doğal yaşam, duyusal, sağlık ve manyetik etkiler konusundaki duyarlıık tespitleri ile uluslararası çalışmalarla tutarlılık göstermektedir (örnek: Cavallaro ve Ciralo, 2005; Drewitt vd., 2006; Haugen, 20II; Kaya ve Kahraman, 2010; Toja-Silva vd., 2013). Bununla birlikte, araştırma bulguları İzmir'e özgü bazı konuları da öne çıkartmaktadır. Özellikle, yurtdışında yapıımış çalışmalarda çok sık irdelenmeyen, tarım ve hayvancılık gibi ekonomik faaliyetlere rüzgâr enerjisi üretiminin etkisinin olduğunu ve toplumun bununla ilgili bir duyarlılık geliştirdiğini ortaya koymaktadır. Bir başka anlamlı farklıık, çalışmaya katılan kişilerin, bu konularla ilgili olumsuz değerlendirmelerini "başkalarından duyduğuna dayanarak" yaptığını ifade etmiş olmasıdır. Bu yüzden bulgular, kişilerin bireysel deneyimlerinden ziyade toplumsal deneyim ve bu deneyimin kolektif algısını da göstermektedir.
Çalışma bulguları, gürültü gibi kişinin sağlığını doğrudan etkileyen bir sorunun olduğu ipuçlarını da vermektedir. Buna istinaden, rüzgârdan enerji üretimi gibi sosyal ve çevresel etkileri olduğu kanıtlanmış büyük bir üretim altyapısının yakınlarında yaşamaktan kimilerinin rahatsı olması, kimilerinin olmaması bir uzlaşma boyutunu aşmaktadır. Eğer rüzgârdan enerji üretilmesinden kaynaklı gerçekten bir takım fiziksel veya psikolojik sağlık sorunları yaşanıyorsa; bu durum baş etmesi, üstünde uzlaşı sağlanması zor bir durumdur. Duyum temelli bazı ifadeler kolektif bir duyarılıık algııının oluşmuş olduğuna işaret etse de toplumda oluşmuş bir duyarlılığa yüklenecek müdahalelerin durdurulması gerekecektir. Buna yüklenmek toplumda telafi edilemez huzursuzluklara neden olabilmektedir.

İkinci olarak, çalışmanın bulguları, İzmir'de özellikle doğal ve insan faaliyetlerinin gerçekleştiği alanların yakınlarında yer seçen rüzgâr tesislerinin etkilerinin genişlediğini ve yoğunlaştığını göstermektedir. Bu bulgular, tesis yakınlığının algıları değiştirdiğini gösteren çalışmaları da (örnek: Krohn and Damborg, 1999; Simon, 1996) destekleyici niteliktedir. Rüzgâr tesislerinin, doğal ve toplumsal alanlara olan mesafesinin arttırılması ve kümülatif etki yaratma olasıı̆ı̆ı açısından çevredeki rüzgâr tesisleri ile birlikte toplam türbin sayısının denetlenmesi bu alanları rahatlatabilir. Çalışma, Avrupa ülkelerindeki bazı uygulamalarla da tutarlı olarak (Yetiş vd., 20।5), tesislere yerleşimlere I km'nin üzerinde bir uzaklıkta yer seçildiğinde etkilerinin hafifleyebileceğini doğrulamaktadır. Ancak, örneğin Avusturalya'da gerçekleştirilen büyük katılımlı anket çalışmaları yerleşimlere $10 \mathrm{~km}$ uzaklıkta dahi yer seçen rüzgâr tesislerini tercih etmeyen beşte birlik (\%2I) bir kesimin olduğunu göstermektedir (AMR Interactive, 20l0). Bu oran I-2 km uzaklıktaki tesisler için neredeyse yarı yarıyadır (\%40).

Üçüncü olarak, çalışma, yetersiz iletişim ve halkın yer seçim karar verme süreçlerine katılımının sadece danışma düzeyinde kısıtlanmasının duyarlılıkların artmasına zemin hazırlıyor olduğunu desteklemektedir. Bu, rüzgârdan enerji üretiminde bilgilenmenin, karar verme süreçlerine katılımın, ekonomik getirilerine ortak olmanın toplumsal algıyı değiştirebileceğini 
gösteren çalışmalarla (örnek; Gype, 1995; Haggett ve Toke, 2006; Krohn ve Damborg, 1999; Sonnberger ve Ruddat, 2017) tutarlılık göstermektedir. Türkiye'de rüzgârdan enerj üretiminin yaygınlaşması için merkezi düzeyde yukarıdan aşağıya hiyerarşik bir yapı içinde yürütülen planlama ve uygulama süreçleri mevcuttur ve giderek artmaktadır. Yukarıdan aşağıya gelen yönergeler ve talimatlarla yürütülen fiziksel planlama süreçleri, özellikle yerel ölçekte, kamusal yararın korunmas ile çelişmektedir. Rüzgârdan enerji üretiminin yer seçimine karar verme süreçlerinde yerel halkın görüşü dikkate alınmalıdır. Böyle bir uygulama, hem bu sürecin demokratikleşmesine katkı sağlayacak hem de yerel halk ile bilgilendirme anlamında ve halkın aktif yurttaşlık rolünün güçlenmesi açısından etkili bir iletişim kanalı kurmaya fırsat verecektir.

Rüzgârdan enerji üretim sürecinin yereldeki planlama süreci ile halkın katılımı sağlanarak yönetilmesi, ortak yerel ekonomik yaşamı güçlendirmeye ve sosyo-mekânsal etkileri zayıflatmaya katkı sağlayacaktır. Bununla birlikte, katılımlı uygulamaların yöntemsel olarak bazı iyileştirmelere açık olduğu ve katılımlı mekanizmaların işletilmesinin ötesinde, rüzgârdan enerji üretim alanları ile ilgili yerelin kolektif ret algısının karar verme sürecinde dikkate alınması gerekliliği de bu çalışmanın derinlemesine incelenmesi gereken başka önemli bir çıktısıdır.

Rüzgârdan enerji üretiminin ekolojik faydasının yerel faydaya dönüşmesi arasında örülmesi gereken bağlar olduğu açıktır. Küresel ve ulusal düzeydeki teknolojik gelişmeler; yerelde uygulandığı zaman doğal yaşamda, tarım ve hayvancılık faaliyetlerinde ve halk sağlığında bazı etkiler doğurmaktadır. Bu çalışma, rüzgâr enerji üretiminin sadece merkezi düzeyde yürütülebilecek bir teknolojik süreç olmadığını, yerelde toplumsal düzeyde oluşan duyarııık alanları ile uyumlandığı koşulda uygulama alanı bulabileceğini doğrulamaktadır.

\section{Teşekkür}

Bu çalışma Orta Doğu Teknik Üniversitesi'nde BAP-08-II2016-004 numaralı Bilimsel Araştırma Projesi olarak desteklenmiştir. Saha çalışmasının gerçekleştirilmesinde destek sağlayan ODTÜ RÜZGEM'e ve İzmir Büyük Şehir Belediyesi'ne; makalenin geliştirilmesinde değerli katkılarını sunan özel sayı editörü Prof. Dr. Ayda Eraydın'a, makale hakemlerine ve son okuma aşamasındaki geri bildirimleri için Tuğçe Savran'a teşekkür ederiz.

\section{KAYNAKLAR}

Aitchison, C. (2004). The Potential Impact of Fullabrook Wind Farm Proposal, North Devon: Evidence Gathering of the Impact of Wind Farms on Visitor Numbers and Tourist Experience. University of the West of England/Devon Wind Power, Bristol.

Aitchison, C. (2012). Tourism Impact of Wind Farms. University of Edinburgh, U.K.

Aitken, M., (2010). Why we still don't understand the social aspects of wind power: A critique of key assumptions within the literature. Energy Policy, 38(4): 1834-1841.

Altaş, İ. H., (1998). Yenilenebilir Enerji Kaynakları ve Türkiyédeki Potansiyeli. Enerji, Elektrik, Elektromekanik-3e, 45, 58-63.

AMR Interactive. (2010). Community attitudes to wind farms in NSW. https://www.environment.nsw.gov.au/resources/communities/100947. wind-farms-community-attitudes.pdf (Erișim Tarihi 07. 03. 2021)

Ataöv, A., Eraydin, A. (2011). Different forms of governance: Responses of two metropolitan regions in Turkey to state restructuring. Urban Affairs Review, 47(1), 84-128.

Aydın, İ. (2013). Balıkesir'de Rüzgâr Enerjisi. Eastern Geographical Review, 18(29), 29-50.

Aydın, N.Y., Kentel, E., Düzgün, H.S. (2013). GIS-based site selection methodology for hybrid renewable energy systems: A case study from western Turkey. Energy Conversion and Management, 70, 90-106.

Baban, S.M.J., Parry, T. (2001). Developing and applying a Gis-assisted approach to locating wind farms in the UK. Renewable Energy, 24, 59-71.

Bakker, R.H., Pedersen, E., van den Berg, G.P., Steward, R.E., Lok, W., Bouma, J. (2012). Impact of wind turbine sound on annoyance, self-reported sleep disturbance and psyhological distress. Science of the Total Environment, 425, 42-51.

Bishop, I.D. (2002). Determination of thresholds of visual impact: the case of wind turbines. Environment and Planning B: Planning and Design, 29,707-718.

Bishop, I.D., Miller, D.R. (2007). Visual assessment of off-shore wind turbines: The influence of distance, contrast, movement and social variables. Renewable Energy. 32, 814-831.

Bishop, K., Proctor, A., (1994). Love Them or Loathe Them? Public Attitudes Towards Wind Farms in Wales. University of Cardiff, Cardiff.

Breglio, V. (1997). Sustainable Energy Budget Coalition Survey (1995 y1lı baskis1). Washington.

Burleson E. (2009). Wind power, national security and sound energy policy. Heinonline.

Burningham, K. (2000). Using the language of NIMBY: A topic for research, not an activity for researchers. Local Environment, 5(1), 55-67.

Cavallaro F, Ciraolo L. A. (2005). Multicriteria approach to evaluate wind energy plants on an Italian island. Energy Policy, 33, 235-244.

Clarke A. (1991). Wind energy progress and potential. Energy Policy, 19, 742-55.

Dai, K., Bergot, A., Liang, C., Xiang, W-N., Huang, Z. (2015). Environmental issues associated with wind energy - A review. Renewable Energy, 75, 911-921.

Daugarrd, N. (1997). Acceptability study of wind power in Denmark. Copenhagen. Energy Centre Denmark.

Devine-Wright, P. (2005). Beyond NIMBYism: towards an integrated framework for understanding public perceptions of wind energy. Wind Energy, $8(2), 125-139$.

Devine-Wright, P. (2007). Reconsidering public attitudes and public acceptance of renewable energy technologies: a critical review. School of Environment and Development, University of Manchester, UK.

Drewitt, A.L., Langston, R.H.W. (2006). Assesing the impacts of wind farms on birds, International Journal of Avian Science, 148(1), 29-42.

DuPont, R. L. (1981). The Nuclear Power Phobia. Business Week, 7 Kasım, 
14-16.

DWTMA (Danish Wind Turbine Manufacturers Association). (1993). Holdningsundersogelse, Ringkjobing. Denmark.

Eraydin, A. (2009). Rethinking globalization and social change: Globalisation, labour markets and social interaction patterns. N. Z. Gulersoy, F. Gezici, A. B. Önem, K. Y. Arslanlı (Ed.), New approaches in urban and regional planning içinde (s. 69-88). Istanbul: Istanbul Teknik Üniveristesi.

Eraydin, A., Tasan Kok, T., Vranken, J. (2010). Immigrant entrepreneurship and contribution of different forms of social integration in economic performance of cities. European Planning Studies, 18 (4), 521-43.

European Environmental Agency (EEA). (2009). Europe's onshore and offshore wind energy potential - An assessment of environmental and economic constraints. EEA Technical Report, No 6/2009.

Evans, B., Parks, J., \& Theobald, K. (2011). Urban wind power and the private sector: Community benefits and public engagement. Journal of Environmental Planning and Management, 54(2), 227-244.

Güzel, A. (2012). Rüzgar enerji santralleri ve halkın kabulü: Çanakkale-Erenköy örneği. Basılmamış Yüksek Lisans Tezi, Çanakkale Onsekiz Mart Üniversitesi, Çanakkale.

Gype, P., (1995). Wind energy comes from age, New York.

Haggett, C., Toke, D. (2006). Crossing the Great Divide - Using Multi-method Analysis to Understand Opposition to Windfarms, Public Administration 84 (1), 103-120.

Harper M., Anderson, B., James, P.A.B., Bahaj, A. S. (2019). Onshore wind and the likelihood of planning acceptance: Learning from a Great Britain context. Energy Policy, 128, 954-966.

Haugen, K.M.B. (2011). International Review of Policies and Recommendations for Wind Turbine Setbacks from Residences: Setbacks, Noise, Shadow Flicker, and Other Concerns. Minnesota Department of Commerce: Energy Facility Permitting.

IFC (International Finance Corpration), WBG (World Bank Group). (2007). Environmental, Health, and Safety Guidelines for Wind Energy.

International energy Agency (IEA). (2015). World Energy Outlook Special Report on Energy and Climate Change.

IPPC (International Panel on Climate Change). (2012). Renewable Energy Sources and Climate Change Mitigation - Special Report of the Intergovermental Panel on Climate Change. Cambridge University Press, New York, USA.

IPPC (International Panel on Climate Change). (2020). Climate Change and Land - An IPCC Special Report on climate change, desertification, land degradation, sustainable land management, food security, and greenhouse gas fluxes in terrestrial ecosystems. https://www.ipcc.ch/site/assets/uploads/sites/4/2020/02/SPM_Updated-Jan20.pdf

IPSOS. (2010). Ipsos Global Energy Barometer:Attitudes Towards Energy Sources. http://www.ipsos.com/public-affairs/sites/www.ipsos.com. public-affairs/files/documents/Ipsos EnergyBarometer.pdf (ErişimTarihi 07. 03. 2021)

IPSOS. (2012). After Fukushima: Global Opinion on Energy Policy. Ipsos Public Affairs. http://www.ipsos.com/public-affairs/sites/www. ipsos.com.public-affairs/files/Energy\%20Article. pdf (Erişim Tarihi 07.03.2021)

Kaya, T. ve Kahraman, C. (2010). Multicriteria renewable energy planning using an integrated fuzzy VIKOR \& AHP methodology: The case of İstanbul. Energy, 35, 2517-2527.

Kılıç, Ç., Yılmaz, M., Sarı, R., (2017). Rüzgâr enerji sistemlerinin sosyal kabul dinamiklerini anlama”. Coğrafi Bilimler Dergisi, 15 (2), 135- 156.

Klepinger, M. (2007). Michigan Land Use Guidelines for Siting Wind Energy Systems. ExtensionBulletinWO-1053. (https://www.canr.msu.edu/uploads/resources/pdfs/michigan_land_use_guidelines_for_siting_wind_ energy_systems.pdf. Erişim Tarihi: 19.01.2021)

Koç, T. (1996). Kapıdağı Yarımadasında Rüzgâr ve Ortam. Türk Coğrafya Dergisi, 31, 167-182.
Kraft, M. E.; Clary, B. B. (1991). Citizen participation and the NIMBY syndrome: Public response to radioactive waste disposal. The Western Political Quarterly, 44, 299-328.

Krohn, S. ve Damborg, S. (1999). On the public attitutdes towards the wind power, Renewable Energy, 16, 954-960.

Lima, F., Ferreira, P., Vieira, F. (2013). Strategic impact management of wind power projects. Renewable and Sustainable Energy Reviews, 25, 277 . 290.

Mikołajczak, J., Borowski, S., Marć-Pieńkowska, J., Odrowąż-Sypniewska, G., Bernacki, Z., Siódmiak, J., Szterk, P. (2013). Preliminary studies on the reaction of growing geese (Anser anser $f$. domestica) to the proximity of wind turbines. Polish Journal of Veterinary Sciences, 16(4), 679-686.

Mulvaney, K.K., Woodson, P., Prokopy, L.S. (2013). A tale of three counties: Understanding wind development in the rural Midwestern United States. Energy Policy, 56, 322 - 330.

Munday, M., Bristow, G., Cowell, R. (2011). Wind farms in rural areas: How far do community benefits from wind farms represent a local economic development opportunity?. Journal of Rural Studies, 27(1), 01 - 12.

Nguyen, K. Q. (2007). Impacts of wind power generation and CO2emission constraints on thefuture choice of fuels and technologies in the power sector of Vietnam. Energy Policy, 35, 2305-2312.

NIA (Northern Ireland Assembly). (2013). Wind Turbines: Planning and Seperation Distances. NIAR 767-13.

NWCC (National Wind Coordinating Committee). (1999). Studying Wind Energy /Bird Interactions: A Guidance Document - Methrics and Methods for Determining or Monitoring Potential Impacts on Birda at Existing and Proposed Wind Energy Sites, Washington DC.

Omnibus Report. (1995). Public Attitutes Toward Wind Energy. Canadian Wind Energy Association and Environmental monitor, Toronto.

Özçam, Z. (2016). Rethinking Wind Energy in Its Social Context: Conflicting Perspectives and Planning Problems - The Karaburun Experience, Basılmamış Yüksek Lisans Tezi, Orta Doğu Teknik Üniversitesi. Fen Bilimleri Enstitüsü, Ankara.

Özgener, Ö. (2002). Türkiye'de ve Dünyáda Rüzgâr Enerjisi Kullanımı. DEÜ Mühendislik Fakültesi Fen ve Mühendislik Dergisi, 4(3), 159- 173.

Palabıyık, H., Yavaş, H., Aydın, M. (2010). Türkiyéde Nükleer Santral Kurulabilir mi? Çatışmadan Uzlaşıya: Türkiye'de Nükleer Enerji Projelerinde Sosyal Kabul Sorunu ve Halkın Reddetme Sendromunun Araştırılması. Girişimcilik ve Kalkınma Dergisi, 5(2), 175 - 201.

Pearce-Higgins, J.W., Stephen, L., Douse, A., Langston, R.H.W. (2012). Greater impacts of wind farms on bird populations during construction than subsequent operation: results of a multi-site and multi-specie analysis. Journal of Applied Ecology, 49, 386-394.

Peker, Z. (2005). Integrating Renewable Energy Technologies into Cities Through Urban Planning: In The Case Of Geothermal and Wind Energy, Basılmamış Doktora Tezi, İzmir Yüksek Teknoloji Üniversitesi. Mühendislik ve Fen Bilimleri Enstitüsü, İzmir.

Peker, Z. (2013). Yenilenebilir Enerji Gelişimlerinin Sosyal Boyutu. Dokuz Eylül Üniversitesi Sosyal Bilimler Enstitüsü Dergisi, 15(4), 663-691.

Pierpont, N. (2009). Wind turbine syndrome: a report on a natural experiment, K-Selected Books, Santa Fe, NM, US.

Premalatha, M., Abbasi, T., Abbasi, S. A. (2014). Wind energy: Increasing deployment, rising environmental concerns. Renewable and Sustainable Energy Reviews, 31, 270-288.

Ramirez-Rosado I.J., Garcia-Garrido E., Fernandez-Jimeneza A., ZorzanoSantamaria P.J., Monteiro C., Miranda V. (2008). Promotion of new wind farms based on a decision support system. Renewable Energy, 33 , 558-66.

Schaub, M. (2012). Spatial distribution of wind turbines is crucial for the survival of red kite populations. Biological Conservation, 155, 111-118.

Short, L. (2002). Wind Power and English landscape identity, İçinde Wind Power in View: Energy Landscapes in a Crowded World, Academic 
Press, San Diego, 43-58.

Simon, A. M. (1996). A Summary of Research Conducted into Attitudes to Wind Power from 1990-1996. Planning and Research for British Wind Energy Association, London.

Sonnberger M.,Ruddat,M. (2017). Local and socio-political acceptance of wind farms in Germany. Technology in Society, 51, 56-65.

Starling, J. (2006). Public Perception of Wind Farms: Opinion of Local Residents at a Developed and Proposed Wind Farm, Yayınlanmamış Tez, University of the West of England, Bristol.

Swofford, J.; Slattery, M. (2010). Public attitudes of wind energy in Texas: Local communities in close proximity to wind farms and their effect on decision-making. Energy Policy, 38, 2508-2519.

T.C. Enerji ve Tabi Kaynaklar Bakanlı̆̆ı (2014). Türkiye Ulusal Yenilenebilir Enerji Eylem Planı. https://kusip.gov.tr/kusip/yonetici/tematikAlanEkGoster.htm?id=75 (Erişim Tarihi: 07.03.2021)

Telleria, J.L. (2009). Potential impacts of wind farms on migratory birds crossing Spain. Bird Conservation International, 19(2), 131-136.

Tester J.W., Drake E.M., Driscoll M.J., Golay M.W., Peters W.A. (2005). Sustainable energy; choosing among options. Cambridge, MA: The MIT Press.

Tetra Tech EC Inc, Nixon Peabody LLP, Comsearch, Avian Systems Inc. (2008). Wind Energy Siting Handbook. http://awea.files.cms-plus. com/AWEA_Siting_Handbook_Feb2008.pdf.

Toja-Silva, F., Colmenar-Santos, A., Castro-Gil, M. (2013). Urban wind energy exploitation systems: Behaviour under multidirectional flow conditions - Opportunities and challenges. Renewable and Sustainable Energy Reviews, 24, 364-378.

Torres-Sibille, A.D., Cloquell-Ballester, V.A., Cloquell-Ballester, V.A., Darton, R. (2009). Development and validation of a multicriteria indicator for the assessment of objective aesthetic impact of wind farms. Renewable \& Sustainable Energy Reviews, 13,40-55.

Tsoutsos, T., Tsouchlaraki, A., Tsiropoulos, M. Kaldellis, J. (2009) [b]. Visual impact evaluation methods of wind parks: Application for a Greek Island. Wind Engineering, 33, 83-92.

Tsoutsos, T., Tsouchlaraki, A., Tsiropoulos, M. Serpetsidakis M. (2009) [a]. Visual impact evaluation of a wind park in a Greek island. Applied Energy, 86, 546-553.

Türkiye elektrik İletim (TEIAŞ). (2018). Türkiye elektirk üretim-iletim 2018 yılı İstatistikleri, Türkiye Elektrik Enerjisi Üretiminin Kaynaklara Göre Dağılımı, (https://www.teias.gov.tr/tr-TR/turkiye-elektrik-uretim-iletim-istatistikleri 06.08.2020)

Türkiye Rüzgar Enerjisi Birliği (TÜREB). (2019). Türkiye Rüzgar Enerjisi İstatistik Raporu Temmuz 2019, Ankara.

U.S. EPA (2013). Renewable Energy Fact Sheet: Wind Turbines. (http:// water.epa.gov/scitech/wastetech/upload/Wind-Power.pdf. 12.08.2016)

Van der Horst, D. (2007). NIMBY or not? Exploring the relevance of location and the politics of voiced opinions in renewable energy siting controversies. Energy Policy, 35(5), 2705-2714.

Voivontas D. Assimacopoulos D, Mourelatos A, Corominas J. (1998). Evaluation of renewable energy potential using a GIS decision support system. Renewable Energy, 13(3), 333-344.

Wang J, Jing Y, Zhang C, Zhao J. (2009). Review on multi-criteria decision analysis aid in sustainable energy decision-making. Renewable and Sustainable Energy Reviews, 13, 2263- 2278.

Warren, C. R.; McFadyen, M. (2010). Does community ownership affect public attitudes to wind energy? A case study from south-west Scotland. Land Use Policy, 27(2), 204-213.

Warren, C.R. \& Birnie, R. V. (2009). Re-powering Scotland: Wind Farms and the 'Energy or Environment?' Debate. Scottish Geographical Journal, 125(2), 97-126.

Wolsink M., (2007). Planning of renewables schemes: Deliberative and fair decision-making on landscape issues instead of reproachful accusations of non-cooperation. Energy policy, 35(5), 2692-2704.

Wolsink M., Sprengers, (1993). Wind Turbine Noise: A New Environmental Threat? University of Amstherdam.

Wolsink, M. (1988). The Social Impact of a Large Wind Turbine, Environ Impact Assess Rev. no. 8, 323-334.

Wolsink, M. (2000). Wind Power and the NIMBY-myth: institutional capacity and the limited significance of public support. Renewable Energy, 21, 49-64.

Wolsink, M. (2012a) "Wind power: Basic challenge concerning social acceptance", Renewable Energy Systems, 1785-1821.

Wüstenhagen, R.; Wolsink, M.; Bürer, M.J. (2007). Social acceptance of renewable energy innovation: An introduction to the concept. Energy Policy, 358(5), 2683-2691.

Yetiş, Ü., Kentel, E., Severcan, Y.C., \& Türel, A., (2015). Rüzgar Enerjisi Santralleri Raporu. Muğla Belediyesi.

Young, B. (1993). Attitudes Towards Wind Power: A Survey of Opinion in Cornwall and Devon. Department of Trade and Industry, London.

Yuan, X.; Zuo, J.; Huisingh, D. (2015). Social acceptance of wind power: A case study of Shandong Province, China. Journal of Cleaner Production, 92, 168-178.

Yue C.D., Wang S.S. (2006). GIS-based evaluation of multifarious local renewable energy sources: a case study of the Chigu area of southwestern Taiwan. Energy Policy, 34, 730-42.

Zahedi, A. (2012). Current Status and Future Prospects of the Wind Energy. IPEC, Conference on Power \& Energy. Ho Chi Minh City. 